\title{
Immigration Policy and Foreign Population in Switzerland*
}

\author{
by \\ Dominique M. Gross \\ Simon Fraser University
}

\begin{abstract}
With more than 20\%, Switzerland is one of the countries with the largest foreign population. Since 1970, the government has tried to manage the flows of migrants in the hope of reconciling a chronic excess demand for labor with mounting pressures from nationalistic groups to control the level of foreign population. A policy of quotas on working permits has been effective in controlling entry of new workers. Nevertheless, the overall dynamics of the system has led to an ever-increasing share of newcomers not covered by quotas. Because of institutional and economic changes, the outflow did not react to economic incentives as the government expected. Hence, at the beginning of the $21^{\text {st }}$ century, the link between the instruments of immigration policy and its goal has become very weak and the level of foreign population is at an all time high. However, a new era has begun with an agreement on free mobility with EU/EFTA countries.
\end{abstract}

World Bank Policy Research Working Paper 3853, February 2006

The Policy Research Working Paper Series disseminates the findings of work in progress to encourage the exchange of ideas about development issues. An objective of the series is to get the findings out quickly, even if the presentations are less than fully polished. The papers carry the names of the authors and should be cited accordingly. The findings, interpretations, and conclusions expressed in this paper are entirely those of the authors. They do not necessarily represent the view of the World Bank, its Executive Directors, or the countries they represent. Policy Research Working Papers are available online at http://econ.worldbank.org.

\footnotetext{
* I thank M. Schiff and an anonymous reviewer for their insightful comments on an earlier draft. I also thank the University of Geneva for its hospitality while writing this paper and the Federal Office for Migration in Bern for kindly providing the data.

Corresponding address: Graduate Public Policy Program, Simon Fraser University, Harbour Centre, 515 West Hastings St., Vancouver BC, V6B 5K3, Canada. Phone: 604-268-7878. Fax: 604-291-5288
} 


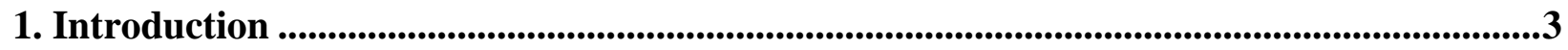

2. Foreign population as a target for immigration policy .................................................................5

2.1. Immigration policy in the 1960s..............................................................................................7

2.2. 1970-1990: The period of global quotas .....................................................................10

2.3. 1990-2002: The period of targeted quotas ...............................................................................19

2.4. Success or failure?.......................................................................................................................22

3. Flows of migrants ........................................................................................................................23

3.1. Long- and short-term immigration ...................................................................................24

3.2. The inflow ...................................................................................................................................29

3.3. The outflow ...............................................................................................................................................34

3.4. Quotas on flows of workers: An evaluation...............................................................................39

4. Who are the foreigners? ................................................................................................................41

4.1. Countries of origin..............................................................................................................................4

4.2. Distribution of skills ......................................................................................................................44

4.3. Distribution across sectors .....................................................................................................46

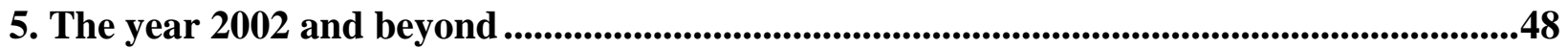

6. Conclusion .....................................................................................................................................50

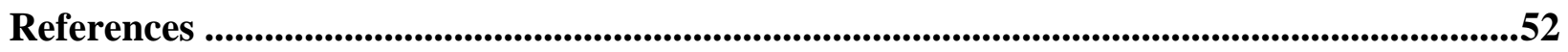

Annex I: Popular votes on immigration ........................................................................................55

Annex II: Historical benchmarks in immigration policy.................................................................57

Table 1.: Foreign population in Switzerland, 1850-2000 .................................................................6

Table 2.: Quotas on one-year and seasonal permits.......................................................................11

Table 3: Composition of foreign labor force (End of December).................................................26

Table 4: Acquisition rate of nationality in some OECD countries ..........................................36

Table 5: Level of sectoral employment ..............................................................................................47

Figures 


\section{Introduction}

Switzerland is one of the developed countries with the largest foreign population, yet it does not see itself as an immigration country. According to official statistics in 2003, there were $1,471,003$ foreigners living in the country, which is $20.1 \%$ of the total population. In comparison, the shares are 10.6\% in France, 9\% in Germany and 6.8\% in Great Britain. Even traditional immigration regions such as North America and Oceania do not exhibit as high a proportion of foreigners. Definitions of the foreign population may vary across countries. However, the US Census Bureau estimates that the foreign born population in the US is 33.5 million or $11.7 \%$ of total population. A figure for Switzerland based on a comparable definition is 15.4\% (US Census Bureau, 2004, p.1; IMES, 2004b, Table S1A08, p.56). While most agree that the phenomenon started in the 1950s, Arlettaz and Arlettaz (2004) show that for all intents and purposes, Switzerland was an immigration country in the $19^{\text {th }}$ century already. In 1850 , the share of foreigners was 3\% and it rose to its first peak in 1910 with $14.7 \%$. It kept declining until after the $2^{\text {nd }}$ World War but has been steadily above $10 \%$ since the 1960 s. Hence, the presence of a relatively large population of foreign origin is not a new phenomenon in Switzerland and yet, immigration policy is still a politically and economically unsolved question. The actual legislation dates from 1931 and an active immigration policy has been in place since the early 1960s.

A specificity of the Swiss immigration policy is the ongoing conflict between economic needs and political pressure from the so-called xenophobic groups. As a consequence, the government through close management of immigration has tried to accommodate demands for increased access to foreign labor by employers and demands by some portion of the population for stricter controls over a constantly rising foreign population. Interestingly, the latter has been 
almost solely addressed through the management of migration flows without much attempt at developing comprehensive integration policies.

This paper shows that for the past 30 years, the government has, on one hand, relied on economic forces and, on the other hand, implemented a policy of quotas to strike a balance between the two conflicting issues. Economic incentives have been expected to drive the outflow of foreigners thereby acting as an automatic stabilizer of foreign population growth (the so-called rotation principle). Government's expectations were validated in the early 1970s, but from the 1980s on, institutional changes and access to more secure residence permits drastically reduced foreigners' incentive to return to their home country. The other feature of the Swiss immigration policy is the fixing of annual quotas for new immigrant workers. While the authorities have been efficient at managing quotas, their link with the overall level of the foreign population has become increasingly remote with time and by 1995 , less than $20 \%$ of the annual inflow was controlled by policy. Therefore, the policy that remained focused on a meticulous management of quotas and on an assumption that was becoming obsolete increasingly failed to influence significantly the level of foreign population.

In the early 1990s external events convinced the Swiss government to reconsider its policy. The refusal by the population for Switzerland to become member of the European Economic Area forces the federal authorities to negotiate agreements with the European Union to maintain open relationships on various economic fronts, including mobility of people. In 2002, an agreement on free mobility with the EU/EFTA started to be implemented, putting an end to the government's ability to control the majority of the inflow of migrants to Switzerland. It is also an opportunity to design new immigration legislation for citizens from the rest of the world and finally put to rest the long lasting conflict between employers' demands and 
xenophobic groups. A project is under discussion in parliament, which should be finalized within a few years to be submitted to popular vote.

The paper is structured as follows: Section 2 presents a survey of the main features of immigration policy in relation to the control of the level of foreign population. Section 3 takes a closer look at the links between the instruments (flows) and the goal (level) of the policy and shows why they became increasingly weak. Section 4 provides a picture of the evolution of some of the characteristics of the immigrants living in Switzerland and Section 5 briefly covers the implementation of the free mobility agreement with EU/EFTA. Section 6 offers some concluding comments.

\section{Foreign population as a target for immigration policy}

For several decades, the target for Swiss immigration policy has been the level of permanent foreign resident population. According to the Federal Statistical Office, the permanent foreign resident population (also called foreign population hereafter) includes all foreigners who reside in Switzerland for at least one year without interruption regardless of the type of permit they hold (i.e., long-term or establishment, one-year and short-term permits renewed for at least a total of 12 months). ${ }^{1}$ These permits allow holders to be active on the labor market; some, however, impose restrictions on mobility. Being born in Switzerland does not entitle to the Swiss citizenship. Thus, statistics on foreign residents include $2^{\text {nd }}$ and $3^{\text {rd }}$ generation migrants. It is estimated that in 2001, 84.6\% of the foreign population aged 15 and more were born abroad and 13.4\% in Switzerland from foreign-born parent (OFS, 2002, Table T5).

\footnotetext{
${ }^{1}$ Asylum seekers, diplomats, international civil servants and their families and seasonal workers are not included in the permanent resident statistics. Note that "permanent" does not have the same meaning as in traditional immigration countries such as Canada or the United States. The various types of permits and their characteristics are detailed in Section 3.
} 
Switzerland has long experienced a relatively large level of foreign population. Already in the late $19^{\text {th }}$ and early $20^{\text {th }}$ century, it was among the few European countries with France who attracted large waves of immigrants in search of political protection as well as work. ${ }^{2}$ In 1850 , the proportion of foreigners in the Swiss population was 3\%; by 1910, it had reached 14.7\% (see Table 1) and with the First World War appeared the first signs of uneasiness about the large number of foreign residents.

Table 1.: Foreign population in Switzerland, 1850-2000

\begin{tabular}{|c|c|c|}
\hline & Number of foreigners & $\begin{array}{c}\text { Foreigners in \% of total } \\
\text { population }\end{array}$ \\
\hline $\mathbf{2 3 . 0 3 . 1 8 5 0}$ & 71,570 & 3.0 \\
\hline $\mathbf{1 0 . 1 2 . 1 8 6 0}$ & 114,983 & 4.6 \\
\hline $\mathbf{1 . 1 2 . 1 8 7 0}$ & 150,907 & 5.7 \\
\hline $\mathbf{1 . 1 2 . 1 8 8 0}$ & 211,035 & 7.5 \\
\hline $\mathbf{1 . 1 2 . 1 8 8 8}$ & 229,650 & 7.9 \\
\hline $\mathbf{1 . 1 2 . 1 9 0 0}$ & 383,424 & 11.6 \\
\hline $\mathbf{1 . 1 2 . 1 9 1 0}$ & 552,011 & 14.7 \\
\hline $\mathbf{1 . 1 2 . 1 9 2 0}$ & 402,385 & 10.4 \\
\hline $\mathbf{1 . 1 2 . 1 9 3 0}$ & 355,522 & 8.7 \\
\hline $\mathbf{1 . 1 2 . 1 9 4 1}$ & 223,554 & 5.2 \\
\hline $\mathbf{1 . 1 2 . 1 9 5 0}$ & 285,446 & 6.1 \\
\hline $\mathbf{1 . 1 2 . 1 9 6 0}$ & 584,739 & 10.8 \\
\hline $\mathbf{3 1 . 1 2 . 1 9 7 0}$ & 982,887 & 15.9 \\
\hline $\mathbf{3 1 . 1 2 . 1 9 8 0}$ & 892,807 & 14.1 \\
\hline $\mathbf{3 1 . 1 2 . 1 9 9 0}$ & $1,100,262$ & 16.4 \\
\hline $\mathbf{3 1 . 1 2 . 2 0 0 0}$ & $1,384,382$ & 19.3 \\
\hline
\end{tabular}

Source: IMES (2004a).

The puzzle that the government has tried to solve for the past 100 years was born: How to accommodate the economy's labor force needs while avoiding the development of xenophobic feelings in some part of the population. Nevertheless, active immigration policies only started in

\footnotetext{
2 This section draws heavily on Arlettaz and Arlettaz (2004), Introduction and Chapter 1; Piguet and Mahnig (2000); Straubhaar and Fischer (1994).
} 
the 1960s and since then three main periods can be distinguished: the 1960 s, 1970 to 1990 and 1990 to 2002. An overview of each period follows and a summary of the main policy changes is given in Annex II.

\subsection{Immigration policy in the 1960s}

The first immigration law dates from 1931 and is still in place. ${ }^{3}$ It mostly describes the conditions attached to various residence permits and the legal rights and obligations of foreigners. The Federal Government and its administration through Government orders define the goals and means of immigration policy. Until the early 1960s, there is no control on immigration: Anybody with a work contract can enter the country and obtain a residence permit once established. Enterprises’ labor requirements are the major source of growth for the foreign population and workers are coming mostly from neighboring European countries. Yet competition for immigrants from Southern Europe is fierce among the wealthier European countries (i.e., Germany, The Netherlands, Belgium and France). Hence, recruiting offices are opened in source countries and bilateral agreements are signed with host countries. Most host countries prefer Italian workers, and the Italian Government uses its position to obtain very early on a preferential treatment for its citizens and also to keep control over emigration. In 1948, Italy signs recruiting agreements with Switzerland and, Spain follows in $1961 .^{4}$ Immigration is a way to improve the flexibility of labor supply and the system is based on the "rotation principle". Foreign workers are seen as guests who need to make money and there is a strong belief that

\footnotetext{
${ }^{3}$ The Federal Legislation on Residence and Establishment of Foreigners (CH, 2004a).

${ }^{4}$ Italy signed an agreement with France in 1947 and with Germany, in 1955 (Gross, 1987, Section 2.2., Footnote 6; Viet, 1998, Chapter 3; Piguet, 2004, Chapter 2).
} 
migrating is a transitory phenomenon in people’s life. ${ }^{5}$ Between 1960 and 1963, on average 364,000 workers enter Switzerland every year. More than half of them (55\%) have a seasonal permit valid for 9 months and are not considered foreign permanent residents; most of the others have one-year work permits (OFE, 2001a, Table 11.1R, p.12). The first attempt at regulating the foreign population occurs in 1963.

Throughout the 1960s, successive attempts by the Government at moderating the overall growth of the foreign population fail. The imposition first of ceilings then, of negative rates of growth on the share of foreign workers in individual enterprises does not generate the expected impact on the size of the foreign population, which keeps rising. Between 1964 and 1969, the number of permanent foreign residents increases on average by $5 \%$ every year to reach 971,795 (15.8\% of total population, see Figure 1).

\footnotetext{
${ }^{5}$ At the time, Germany has a similar understanding of the role of foreign workers and France also with workers from the former colonies (Blanc-Chaléard, 2001, pp.63 and 66-67)
} 
Figure 1: Level of permanent foreign population and unemploymnent rate

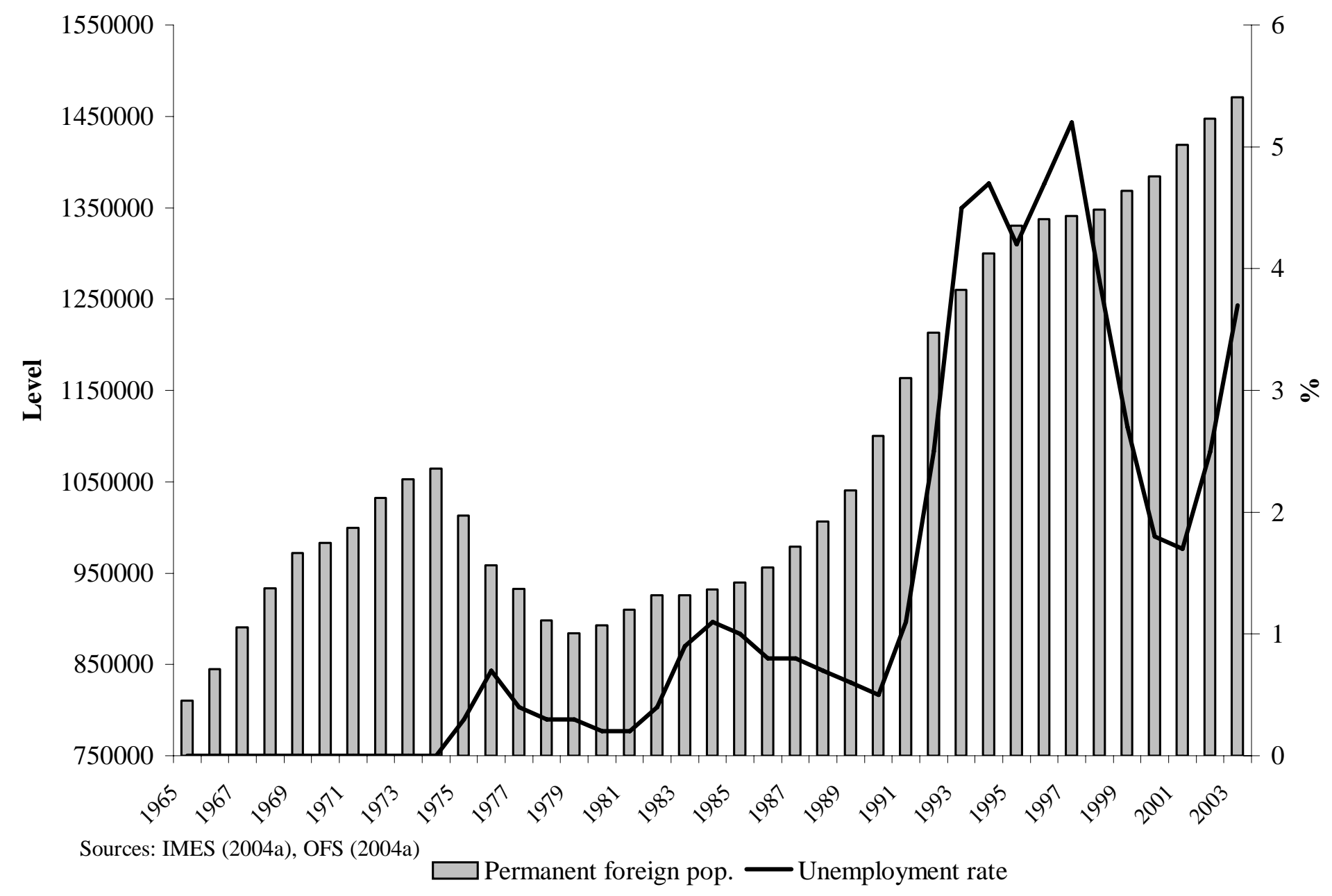


Political pressures keep rising and they materialize in the repeated use of the popular initiative instrument by some groups to force the Government to curb the expansion of the foreign population. ${ }^{6}$ Faced with the failure of its policy of firms' ceilings to slow down the expansion of foreign population, in March 1970 the Government implements a new order which defines explicit overall quotas for new workers' permits. This is the first one in a series of orders aimed at explicitly controlling migration inflows and that policy, by and large, will remain in place until June 2002.

\subsection{0-1990: The period of global quotas}

The stated goal of Swiss immigration policy has always been and still is to control the level of foreign resident population while accommodating the demands from the economy and the so-called global ceiling policy started in 1970 is designed to reconcile these two aims. The policy fixes annual quotas for the number of new permits for foreign workers and is anchored in the management of a centrally administered registry for foreigners. A Government order instructs employers to announce to municipalities' population offices the end of all work contracts with foreign employees and, landlords to do the same with respect to foreign tenants. ${ }^{7}$ Based on the number of foreigners who left the country during the preceding year and following informal contacts with business and cantons' representatives, the federal administration first identifies the annual quota for new permits. In a second phase, the allocation of these permits

\footnotetext{
${ }^{6}$ The first initiative is retired in 1968, when the Government decides to set explicit rates of decrease for the size of foreign employment in individual enterprises. The second initiative, called the "Initiative against foreign ascendancy" has collected the required number of signatures in May 1969 and is put to popular vote in June 1970 (see Annex I of this paper and Piguet and Mahnig, 2000, p.11, for more details).

${ }^{7}$ Government Order on Announcing the Departure of Foreigners (CH, 2004b). Registration of foreign employees and tenants upon arrival is compulsory since 1931 (CH, 2004a, Art. 2).
} 
across the country is organized through consultations and negotiations with social partners and political parties. Every November 1, the Government announces the number of work permits to be available for the next 12 months and its geographical distribution. Initially, a number of permits are allocated to enterprises in cantons, which suffer from an acute shortage of labor and have filed a request. Then, another allocation is made to the cantons proportionately to the population with the distribution of these permits organized by local authorities. By managing the allocation mechanism closely and exempting some industries from the quota system (public health, teaching and agriculture), the Government once again tries to reconcile the needs from a booming economy which in the 3 preceding years (1967-1969) has been growing at an average of 5.2\%, and pressures from organizations commonly referred to as xenophobic groups which regularly threaten to use the initiative right to generate a popular consultation on the issue of “overcrowding by foreigners"8. In the first two years, 1970/71 and 1971/72, around 20,000 new annual work permits are allocated, a sharp drop from the preceding years before quotas were in place (see Table 2).

Table 2.: Quotas on one-year and seasonal permits

\begin{tabular}{|l|c|c|}
\hline & $\begin{array}{c}\text { Quotas on one-year work } \\
\text { permits } \\
\text { (Nov. to Oct.) }\end{array}$ & $\begin{array}{c}\text { Quotas on } \\
\text { Seasonal permits } \\
\text { (Nov. to Oct.) }\end{array}$ \\
\hline $\mathbf{1 9 7 0 - 7 4}$ & Between 22,000 and 10,000 & From 152,000 up to 220,000 \\
\hline $\mathbf{1 9 7 6 - 8 8}$ & Between 7,500 and 10,000 & Between 135,000 and 150,000 \\
\hline $\mathbf{1 9 8 9 - 9 1}$ & From 11,000 up to 17,000 & From 145,000 down to 135,000 \\
\hline $\mathbf{1 9 9 2 - 9 8}$ & 17,000 & From 135,000 down to 88,000 \\
\hline
\end{tabular}

Source: Adapted from Piguet and Mahnig (2000).

\footnotetext{
${ }^{8}$ The $3^{\text {rd }}$ such initiative has collected the required number of signatures in November 1972 and is rejected by popular vote in October 1974 (see Annex I).
} 
This policy is limited to stabilizing new entries. The underlying assumption that foreigners come to Switzerland to make money and then leave (i.e., rotation principle) is still prevailing and accordingly, there is little consideration for integration policies. For example, the Government finances language courses for asylum seekers but not for immigrants (Straubhaar and Fischer, 1994, p.134). Moreover, 9-month work permits for workers in seasonal industries such as hospitality, construction and agriculture (i.e., the so-called guest-workers) are also under quotas. However, because of a lack of strict monitoring by the cantons, the number of permits actually awarded is about $50 \%$ above the limit. In the early 1970s, the quota for seasonal permits is set at 152,000 yearly (Piguet, 2004, p.35), yet, the number of seasonal workers averages 226,222 per year between 1970 and 1973 (OFE, 2001b, Table 11.1R, p.12).

At first, the new policy is far from having the intended impact. The level of foreign population passes the one million mark in 1972 and, by 1974 its share in total population is $16.8 \%$ while it was $15.8 \%$ in 1969 . Nevertheless, the early seventies is also the period of the first oil shock and the Swiss economy is hit severely. In 1973, real growth slows down drastically (1.5\%) and, in 1974, it plunges to $-7.3 \%$ (WB, 2004). The following year, annual growth rate is still negative (-1.4\%) and it is only in 1976 that the economy starts recovering yet at a slow pace. From 1974 until 1976 total employment falls by about 256,000 jobs, of which 171,000 are held by foreigners (see Figure 2). 
Figure 2: Employment of foreign and Swiss populations (,000)

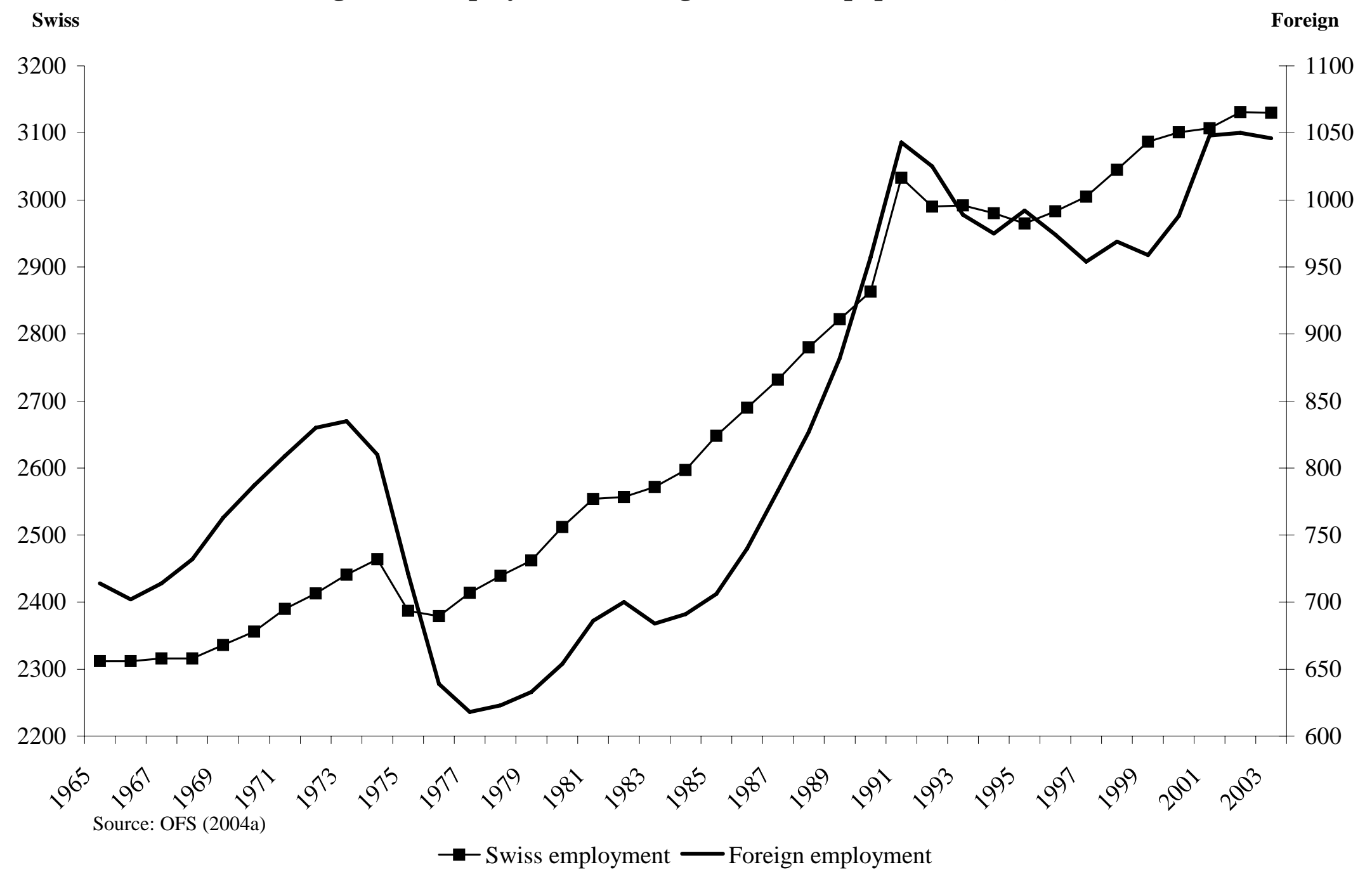


This period is known as the time during which Switzerland used the flexibility of the immigration policy to export unemployment. One reason for this interpretation is that the unemployment rate remains close to zero while the level of foreign population is falling (see Figure 1). Between 1974 and 1978, it decreases by 2.5 percentage points, corresponding to a $15.6 \%$ drop in the number of foreign permanent residents from its all times peak. While it is true that recruitment falls and the number of seasonal workers under quota, during the worst years of the recession, is cut in half (about 97,000 permits), these workers are not registered as permanent residents and cannot account for the fall in the foreign population. It is the outflow of permanent foreign residents that increases drastically during the period (see Figure 3). 
Figure 3: Total inflow and outflow of foreign permanent residents

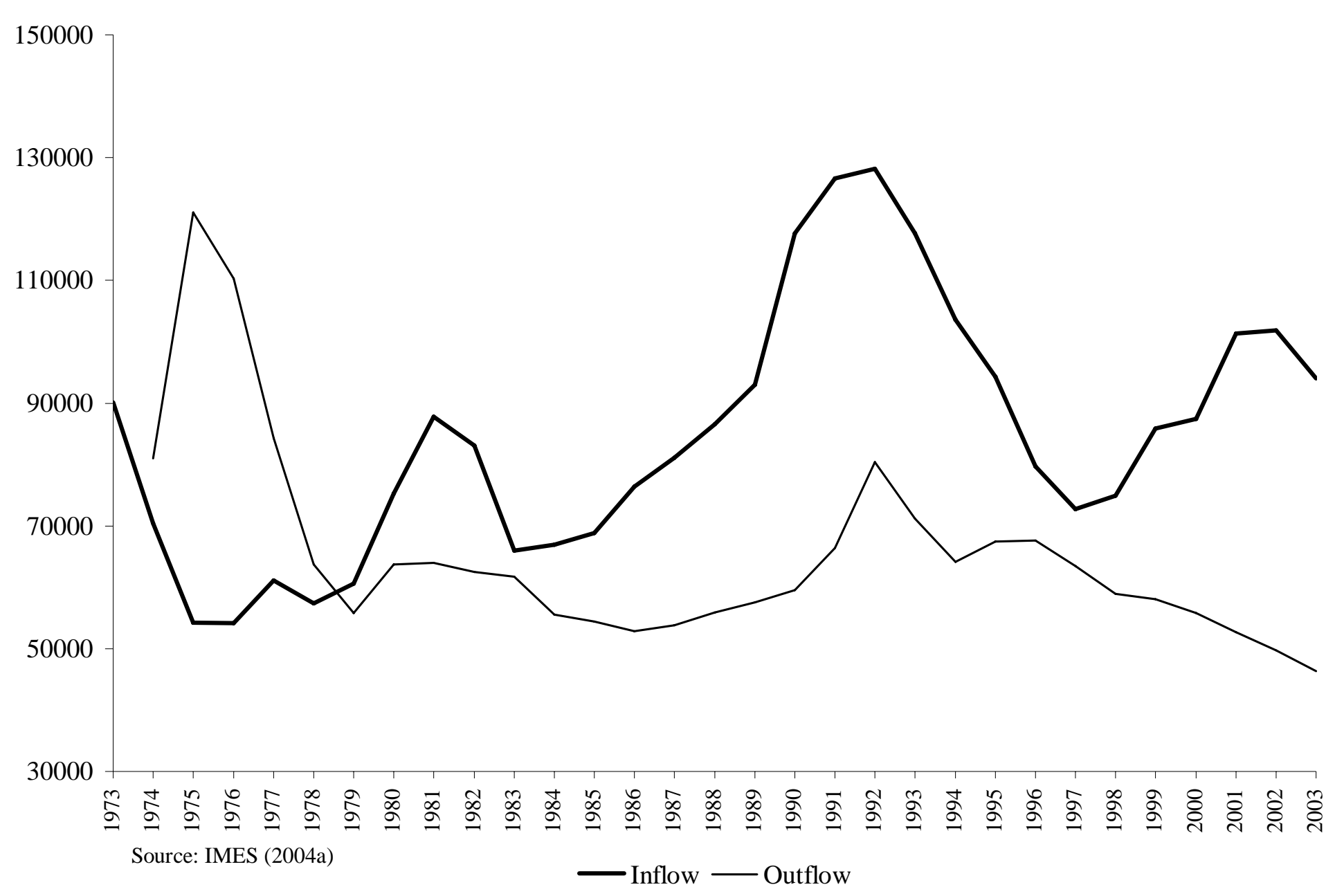


In particular, the number of residents with long-term permits who decide to return to their country more than doubles (from 20,359, in 1974, to 44,827, in 1976). This exodus is often seen as voluntary because there is no legal obligation for these foreign residents, who can stay unconditionally in Switzerland, to emigrate. However, at the time, Switzerland does not have generalized unemployment insurance ${ }^{9}$ and the foreign workforce is hit disproportionately hard by layoffs. Hence, the assumption underlying immigration policy is suddenly validated: Foreign residents who have made some money go back to their country where life is less expensive and where they may feel more integrated. In 1974, Italians and Spaniards make up 63.5\% of the foreign population and income per capita in Switzerland is 3.1 times higher than in Italy and 3.7 times higher than in Spain. Between 1974 and 1976, about 2/3 of emigrants are from Italy and Spain.

The outflow of holders of one-year permits also increases from 60,680 in 1974 to 81,243 in 1975 but quickly falls back to 65,470 in 1976 . Simultaneously quotas on newcomers are tightened and decrease from 20,000 to 10,000 (see Table 2). Hence, stricter quotas also contribute to the negative migration balance. As a consequence, in 1979, the level of foreign population reaches its lowest level since the late 1960s and it will take 10 years to climb back to one million. Yet, pressures for stricter controls are increasing as the economy has difficulties recovering and two more initiatives to limit foreigners' presence with extreme measures are submitted to popular vote in 1977. Both

\footnotetext{
${ }^{9}$ Neither Swiss nor foreign workers are covered by unemployment insurance at the time. The Federal Legislation on Unemployment Insurance and Support in Case of Bankruptcy is implemented on January 1, 1983 (CH, 2003b).
} 
are defeated. ${ }^{10}$ Nevertheless, the Government reacts by developing a new immigration legislation, which is rejected by popular vote in 1982 and, the policy of annual quotas on one-year and seasonal permits remains in place.

Throughout most of the 1980s, annual quotas for new one-year permits are set below 10,000 and, yet the foreign population grows steadily. A new phenomenon is at the source of that evolution: The changing composition of the inflow of foreigners leading to a growing proportion of newcomers not covered by quotas. This arises, in part, because of changes in policy and, in part, because of the natural dynamics of the system. For example, workers with uninterrupted seasonal permits for 10 years can obtain one-year permits and these conversions are not under quota. In 1964, the Italian Government has signed an agreement allowing its citizens to get their seasonal permit converted after 5 years. In 1972, the period is reduced to 4 years and, in 1989 and 1990, Spain and Portugal also obtain a reduction from 10 to 5 years. Hence, guest workers, who kept their jobs throughout the 1970s, progressively gain permanent residency and between 9,000 and 10,000 seasonal permits are converted yearly on average throughout the $1980 \mathrm{~s}^{11}$ Similarly, newcomers accepted under the family reunion class are not subjected to the quotas. Between 1981 and 1990, the inflow of people from that category increases from about 20,000 to 30,000 per year (OFE, 2001a, Table 111.3.R, p.39). Finally, following crises in Turkey, former Zaire, Chili and Sri Lanka the number of asylum seekers increases significantly and, a number of them are accepted as permanent residents in Switzerland for humanitarian reasons (see Piguet, 2004, p.80).

\footnotetext{
${ }^{10}$ Another initiative in support of foreigners which among other things proposes the elimination of the seasonal worker status is also defeated by popular vote in 1981 (see Annex I, Tables A.I.1. and A.I.2.).

${ }^{11}$ See, Figure 6 in Section 3.2 and OFE (2001a), Table 112.4.R, p.43.
} 
As a result quotas fail to impact meaningfully foreign population growth and a $6^{\text {th }}$ initiative on the issue is launched. It is, however, rejected by a small margin in the popular vote sending one more time the signal to the Government that, while the overall population does not want drastic measures, it expects more effectiveness from immigration policy.

The late 1980s is a period of economic growth (3.5\% per year) and foreign workers fill a renewed chronic deficit of labor. The quotas one one-year permits are progressively raised under pressing demands from enterprises and foreign employment rises fast (see Table 2 and Figure 2). Once again, the two goals of Swiss immigration policy are in conflict and new external developments further shrink the Government's room for maneuver. In effect, in the late 1980s, the debate about the position of Switzerland vis-à-vis the European Union (EU) begins and specifically whether Switzerland should join the European Economic Area (EEA), which will integrate EFTA members more closely with the EU members. Free mobility of labor is at the heart of the debate and it is becoming clear that some aspects of the immigration policy (such as seasonal permits) are not compatible with participation in the EEA. Also, in case of participation to the EEA, the quota system would become an even weaker instrument since $2 / 3$ of workers come from EU countries. ${ }^{12}$ The authorities also start realizing that the rotation assumption is no longer sustainable and a large number of immigrants will not return to their country of origin. Redefining the modalities of the immigration policy therefore becomes a necessity.

12 In 1989, 66\% of the new migrants entering the labor force are from EU/EFTA (OFE, 2001a, Table 11.21R, p.16). 


\subsection{0-2002: The period of targeted quotas}

Twenty years of restructuring and two major recessions have transformed the Swiss economy and enterprises complain about the difficulties of hiring foreign skilled labor. According to employers, the quota system favors sectors intensive in unskilled labor and the allocation is too politicized. In 1990, the Government begins the implementation of the "three-circle model" which anticipates on free mobility with EU countries (see Figure 4). 


\section{Figure 4: Circle policies}
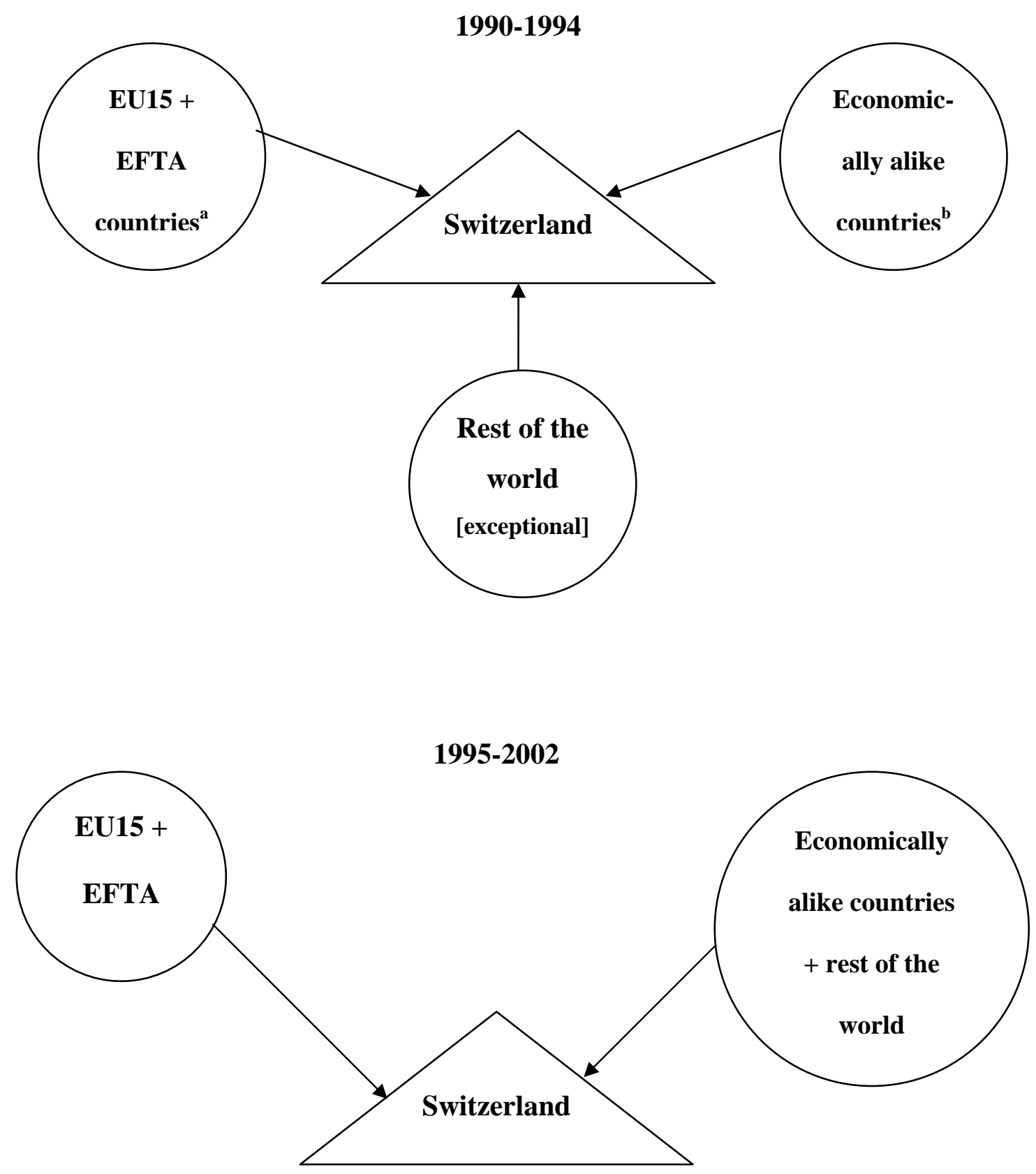

${ }^{a}$ EU15: Austria, Belgium, Denmark, Finland, France, Germany, Greece, Ireland, Italy, Luxemburg, Netherlands, Portugal, Spain, Sweden, UK. EFTA: Iceland, Lichtenstein Norway.

${ }^{\mathrm{b}}$ Australia, Canada, New-Zealand, USA, micro European States and Eastern Europe. 
The new model is designed around three categories of source countries. The first circle, or inner circle, is made of EU and EFTA member countries with which the aim is to reach free mobility and abolish the status of the seasonal worker in the medium term. The second circle, or median circle, is made of countries economically and culturally close to Switzerland such as North America, Oceania, and Eastern Europe. One-year and seasonal permits for all these countries are under quota (17,000 for one-year permits and 135,000 for seasonal permits, see Table 2) and limited to skills in shortage. Finally, the third circle, or outer circle, is made of all other countries from which new immigrants can be accepted only under exceptional circumstances.

In 1990, the Swiss economy plunges in a deep recession and for the next 3 years real GDP will decline. However, the situation on the labor market is fundamentally different from that of the early 1970s as the unemployment rate rises to levels never observed before: From 1.1\% in 1991 to 4.7\% in 1994 (see Figure 1). The employment level of foreigners shrinks more than that of the Swiss (-6.5\% vs. $-1.7 \%$, see Figure 2) and unemployment among foreigners rises rapidly (from $2 \%$ in 1991, to $8.4 \%$ in 1994 against $0.8 \%$ to $3.7 \%$ for the Swiss). Unemployment insurance is now compulsory and benefits are available to all workers and incentives to leave are much weaker than in the 1970s. Even though the outflow of foreign permanent residents increases, the inflow remains much larger (see Figure 3). Consequently, the foreign population keeps growing (+11.8\% from 1991 to 1994, see Figure 1). A large number of seasonal workers have obtained a more stable status in the preceding years and have been able to bring their families thanks to improvements in the regulation. The quotas now limited to a shrinking category of newcomers are less successful than ever in controlling the level of foreign population. 
With unemployment at a level never experienced before, nationalists’ arguments prevail and the population rejects the participation of Switzerland to the EEA in December 1992. Yet, the Government remains determined to increase economic integration with the EU. Thus it starts negotiations with the EU on a number of issues, including fee mobility of people. Also, by 1995, the explicit discrimination embodied in the three-circle policy has become inconsistent with Switzerland signing the International Convention against Racist Discrimination. These events trigger discussions on a project for new immigration legislation and, during the transitory period until the legislation is put in place, a number of changes are implemented. Countries from the $2^{\text {nd }}$ and $3^{\text {rd }}$ circles are merged (see Figure 4) and, seasonal permits are progressively eliminated; quotas for annual permits are raised and skilled workers are targeted for immigration. Employers are advised to fill their needs with migrants from European countries; they can, however, prospect worldwide for skilled workers (Piguet, 2004, p.65). The policy, still based on the 1970 principle of quotas on work permits is in place until 2002.

\subsection{Success or failure?}

Over the 30 years, between 1970 and 2000, there seems to be a constant dissatisfaction from part of the Swiss population with the results of the immigration policy. Yet, it is by far not a complete failure. Controlling closely the level of the foreign population may not have been reached but the quotas have been binding. Moreover quotas on one-year permits have not been filled over several years especially during recession (i.e., 1981-1984 and 1990-1998). For example, between 1991 and 1994, only about 50\% of the permits are allocated (see Piguet and Mahnig, 2000, Figure 15). The rotation assumption which implies that outflow responds to 
economic incentives has not however performed as well. ${ }^{13}$ For the level of foreign population to stabilize the total outflow must follow relatively closely the evolution of the inflow over time. In Figure 3, it is clear that it is not the case. The outflow remains systematically below the inflow and even decreases in the late 1990s, while the inflow increases. Hence, the rotation assumption becomes increasingly inappropriate as permanent foreign residents appear less and less inclined to return to their country "after making enough money".

In the next section, we take a closer look at the inflow and outflow; we analyze their various components and respective impacts on the level of foreign population. We also provide some explanation why the policy lasted for three decades despite its inability to impact the level of foreign population.

\section{Flows of migrants}

Like most European countries, Switzerland has always claimed it is not an immigration country and its policy is labor focused. Since 1970, the Government concentrates on the close management of the inflow of new immigrant workers, through quotas, using two instruments: A direct one, that is an annual quota on one-year work permits; and an indirect one, an annual quota on seasonal work permits, which feed, with several years delay, into the level of permanent residents through conversions into longer term permits. The decision to focus on these two instruments only is anchored in the assumption that economic migrants see migration as temporary that is eventually return home regardless of their status in the new country. Yet, a survey of the conditions of eligibility for different types of permits and institutional changes shows that the dynamics of the system works against this assumption and strongly encourages

\footnotetext{
${ }^{13}$ Between 1991 and 1996, the simple correlation between the outflow and lagged unemployment rate is -0.521
} 
permanent settlement. Hence, for several decades, the system has embodied a deep contradiction between its actual functioning and the expectation of seeing immigrants return to their home country eventually. We start by surveying briefly the types of permits available to newcomers and foreign residents in Switzerland and then, analyze in more depth the composition of inflows and outflows.

\subsection{Long- and short-term immigration}

There are four basic types of permits for newcomers: Short-term permit (i.e., the seasonal permit), one-year permit, establishment permit and cross-border permit. Each one is briefly described in turn. ${ }^{14}$

- The short-term permit until 2001 is only for seasonal work (Permit A). It is delivered for a given jobs, for 9 months over a period of 12 and is renewable. Seasonal workers have the obligation to return to their home country for the months not covered by the permit. After 10 years of uninterrupted seasonal permits, a person can request a one-year permit. Italy, Spain and Portugal, have obtained shorter waiting periods for their citizens (see Section 2.2.). Since 1995, seasonal permits have been available only to citizens from EU/EFTA and they are abolished in 2002. Since then, a new short-term permit (Permit L) is available to skilled foreigners from countries outside the EU/EFTA with a work contract for less than one year. Short-term permits are also allocated to foreigners with a variety of other reasons to come to Switzerland, such as studies, training, retirement and to independently wealthy people. Permits for less than 4 months are not included in the quota. No family reunion allowed.

indicating the outflow decreases as unemployment rises.

14 This section is based on OFE (2002a, 2002b) and CH (2004a). 
- The one-year permit (Permit B) is awarded to foreign workers with work contracts of one year or more. It is automatically renewable with a work contract but an authorization must be sought to change employers or cantons. After 10 years, the permit can be converted into an establishment permit. In 1982 negotiations with Italy reduce the waiting period to 5 years and Spain and Portugal obtain similar conditions in 1989 and 1990 respectively. The permit is also attributed to family members through birth or family reunion. Since 1993, family reunion (i.e., spouse and children under 18) is authorized without waiting period provided workers can offer standard conditions of living for their family.

- $\quad$ The establishment permit (Permit C) is delivered to a family once a worker has fulfilled the required waiting period with permits B (or exceptionally permit A) to family members and newborn of workers with permit C already, and to foreigners who left and return to Switzerland within a certain deadline. The permit has no time limit and entitles to free job and residence mobility. Family reunion is possible at any time. Some municipalities have given voting rights to holders of such permits.

- The cross-border permit (Permit G) is a one-year permit for workers who live in the neighboring border regions and work in the adjacent region of Switzerland. It is valid for one year and renewable. The person must return to a foreign domicile every day. ${ }^{15}$

One characteristics of the system is that holders of permits "graduate" from short- to longer-term permits with time. This feature introduces an independent dynamics in the evolution of the structure of permit categories which has not been taken into account by the quota policy. In 1970, before the introduction of quotas, about $1 / 2$ of the total foreign labor force is under one-

\footnotetext{
${ }^{15}$ Asylum seekers, people admitted temporarily because of undue hardship in their home country are given other types of permits.
} 
year permits and a little less than $1 / 4$, under long-term establishment permits. Also, there are twice as many seasonal workers as cross-border workers (see Table 3).

Table 3: Composition of foreign labor force (End of December)

\begin{tabular}{|c|c|c|c|c|c|}
\hline & $\begin{array}{c}\text { Seasonal } \\
\text { permits }^{\text {a/ }} \\
(\mathbf{\%})\end{array}$ & $\begin{array}{c}\text { One-year } \\
\text { permits } \\
(\mathbf{\%})\end{array}$ & $\begin{array}{c}\text { Establishment } \\
\text { permits } \\
(\mathbf{\%})\end{array}$ & $\begin{array}{c}\text { Cross-border } \\
\text { permits } \\
(\mathbf{\%})\end{array}$ & Total \\
\hline $\mathbf{1 9 7 0}$ & $\begin{array}{c}154,732 \\
(18.8)\end{array}$ & $\begin{array}{c}410,321 \\
(49.9)\end{array}$ & $\begin{array}{c}182,898 \\
(22.2)\end{array}$ & $\begin{array}{c}74,134 \\
(9.0)\end{array}$ & $\mathbf{8 2 2 , 0 8 5}$ \\
\hline $\mathbf{1 9 7 5}$ & $\begin{array}{c}86,008 \\
(11.9)\end{array}$ & $\begin{array}{c}225,371 \\
(31.1)\end{array}$ & $\begin{array}{c}327,234 \\
(45.2)\end{array}$ & $\begin{array}{c}85,180 \\
(11.8)\end{array}$ & $\mathbf{7 2 3 , 7 9 3}$ \\
\hline $\mathbf{1 9 8 0}$ & $\begin{array}{c}109,873 \\
(15.6)\end{array}$ & $\begin{array}{c}126,864 \\
(18.0)\end{array}$ & $\begin{array}{c}374,240 \\
(53.0)\end{array}$ & $\begin{array}{c}94,833 \\
(13.4)\end{array}$ & $\mathbf{7 0 5 , 8 1 0}$ \\
\hline $\mathbf{1 9 8 5}$ & $\begin{array}{c}102,809 \\
(13.4)\end{array}$ & $\begin{array}{c}123,067 \\
(16.1)\end{array}$ & $\begin{array}{c}426,227 \\
(55.7)\end{array}$ & $\begin{array}{c}112,780 \\
(14.7)\end{array}$ & $\mathbf{7 6 4 , 8 8 3}$ \\
\hline $\mathbf{1 9 9 0}$ & $\begin{array}{c}121,704 \\
(12.5)\end{array}$ & $\begin{array}{c}169,937 \\
(17.5)\end{array}$ & $\begin{array}{c}499,865 \\
(51.4)\end{array}$ & $\begin{array}{c}181,366 \\
(18.6)\end{array}$ & $\mathbf{9 7 2 , 8 7 2}$ \\
\hline $\mathbf{1 9 9 5}$ & $\begin{array}{c}53,707 \\
(5.8)\end{array}$ & $\begin{array}{c}185,744 \\
(19.9)\end{array}$ & $\begin{array}{c}542,928 \\
(58.2)\end{array}$ & $\begin{array}{c}150,983 \\
(16,2)\end{array}$ & $\mathbf{9 3 3}, \mathbf{3 6 2}$ \\
\hline $\mathbf{2 0 0 0}$ & $\begin{array}{c}30,999 \\
\mathbf{2 0}\end{array}$ & $\begin{array}{c}181,597 \\
(20.1)\end{array}$ & $\begin{array}{c}535,678 \\
(59.2)\end{array}$ & $\begin{array}{c}155,955 \\
(17.2)\end{array}$ & $\mathbf{9 0 4 , 2 2 9}$ \\
\hline
\end{tabular}

Source: OFE (2001b). ${ }^{a /}$ Peak number at the end of August.

By 1980, after the long decline in the foreign population, the level and share of one-year permit holders has dropped sharply and they represent only $18 \%$ of the total foreign labor force while establishment permit holders represent more than $1 / 2$ of it. Seasonal workers are just a little more numerous than cross-border workers in part because of the decline in seasonal permits now under quotas, and, in part because of a large increase in the cross-border permits ( $+28 \%$ in the decade). As a matter of fact, the latter grows steadily during the entire 30-year period and it is forecasted that free mobility with EU/EFTA the implementation of which started in 2002 will generate even larger increases in coming years. By 1990, as the overall foreign labor force (seasonal, permanent and cross-border workers) is approaching the 1 million mark, the composition has 
hardly changed: One-year permit holders represent $17.5 \%$ and establishment permit holders, 51.4\%. Nevertheless, during the next decade, seasonal permits are converted into one-year permits, and, one-year permits into establishment permits in large numbers, and soon establishment permits represent $60 \%$ of the foreign labor force. Concurrently, seasonal permits are progressively eliminated. Hence, in 30 years, foreign workers on average have gained a much more secure resident status.

Between 1970 and 2000, the Government implements its quota policy strictly yet the control of the level of foreign resident population is not achieved. A closer look at the various components of inflow and outflow can shed some light on the reasons for the weakening of the connection between the instruments and the goal of immigration policy. The main components of the inflow and outflow are depicted in Figure 5. 
Figure 5: Level and flows of foreigners

[1981, 1990, 2000]

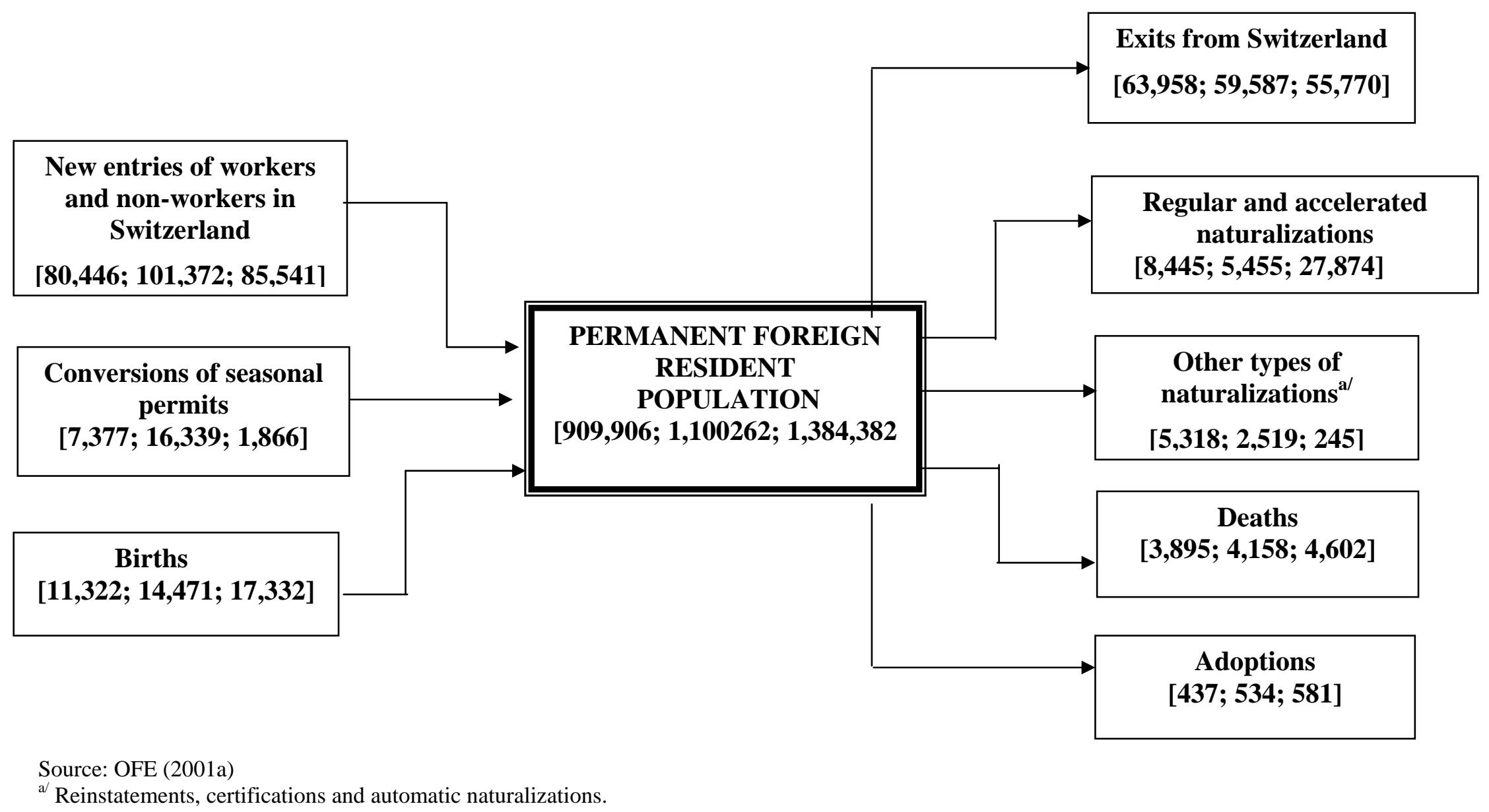


There are 3 ways foreign population can increase: Through new entries into the country, conversions of seasonal permits into longer-term permits and through births from foreign parent. Decreases can occur through exits of residents from Switzerland, naturalizations, adoptions and deaths. The next sub-section analyzes the components of the inflow.

\subsection{The inflow}

The largest category in the inflow is the new migrants category (excluding conversion of seasonal workers), which represents approximately $80 \%$. When the motives for migrations to Switzerland are considered, it becomes clear why quotas focused on new one-year work permits have been inefficient in stabilizing the population level. The share of new entries feeding the permanent foreign resident population and not under quota has evolved inversely with quotas. In 1987, $78.4 \%$ of the inflow are not under quota, in1994, $86.3 \%$ are not. The share falls back to 74.8\% in 2001 as quotas on one-year permits are increased (see Figure 6). 


\section{Figure 6: Inflow of permanent residents by motives}

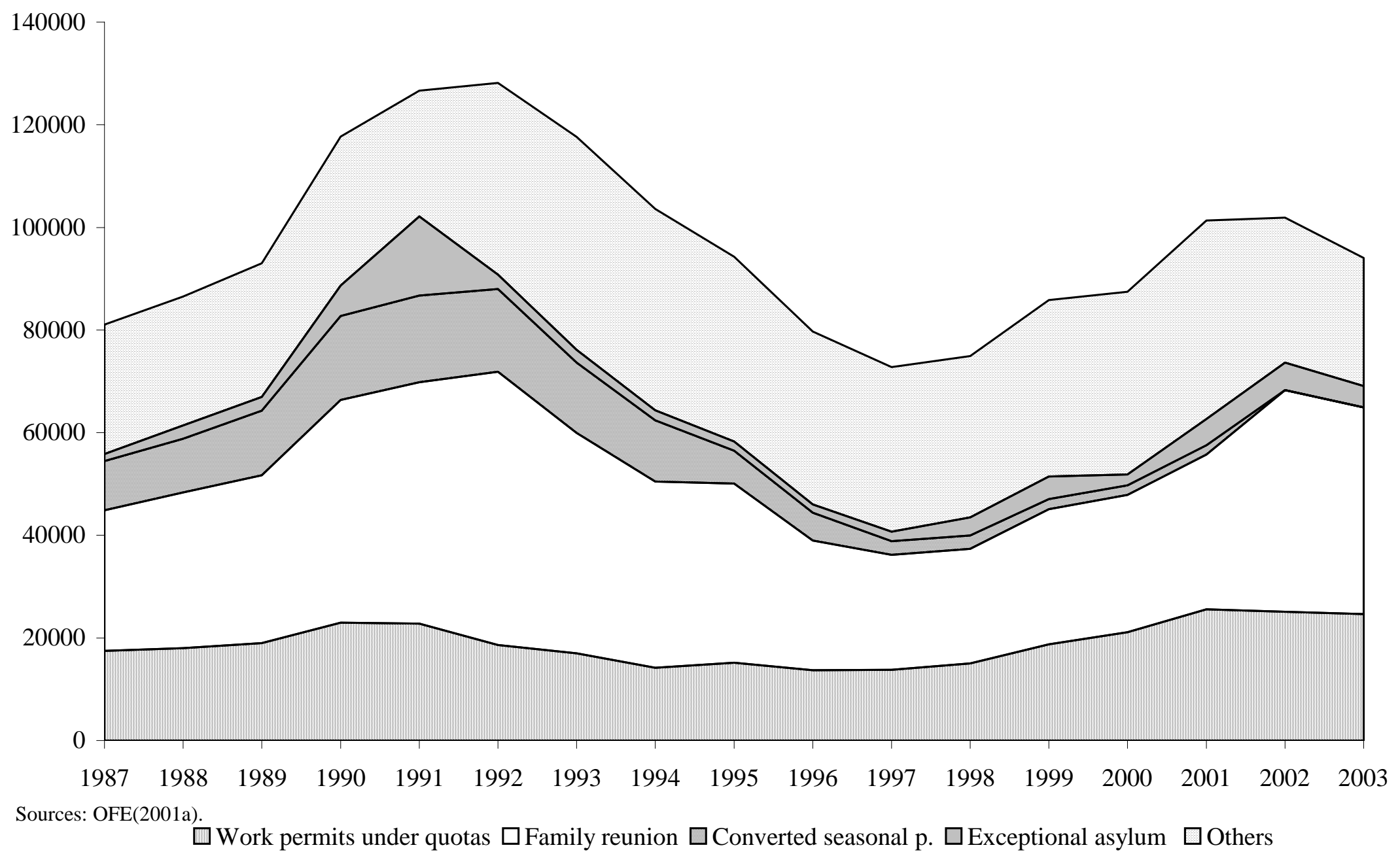


This evolution is due to several factors must. First, people coming to Switzerland through the family reunion class with one-year or establishment permits are not under quota and, the impact of the agreement signed with Spain, in 1989, and with Portugal, in 1990, that reduces the waiting period for family reunification is clear. In effect, between 1990 and 1993, more than 46,000 people, on average, enter Switzerland yearly in that category, that is $2 \frac{1}{2}$ times the size of quota on one-year work permits. Second, political crises in the world (Lebanon, Turkey, Sri Lanka and Former Yugoslavia) increase the number of permits allocated for humanitarian, reasons. The annual number of such permits rises from 2,678 in 1989 to 15,424, in 1991. Note that the category for other motives, (i.e., students, accepted refugees, independently wealthy foreigners) also increases in the early 1990s. Third, while new seasonal permits are under quota, the number of conversions of seasonal permits into longer-term permits is not. Between 1988 and 1989, it rises by 20.3\% and between 1989 and 1990, by 29.8\% (see Figure 7). 
Figure 7: Seasonal workers and conversions of seasonal permits into longer-term permits

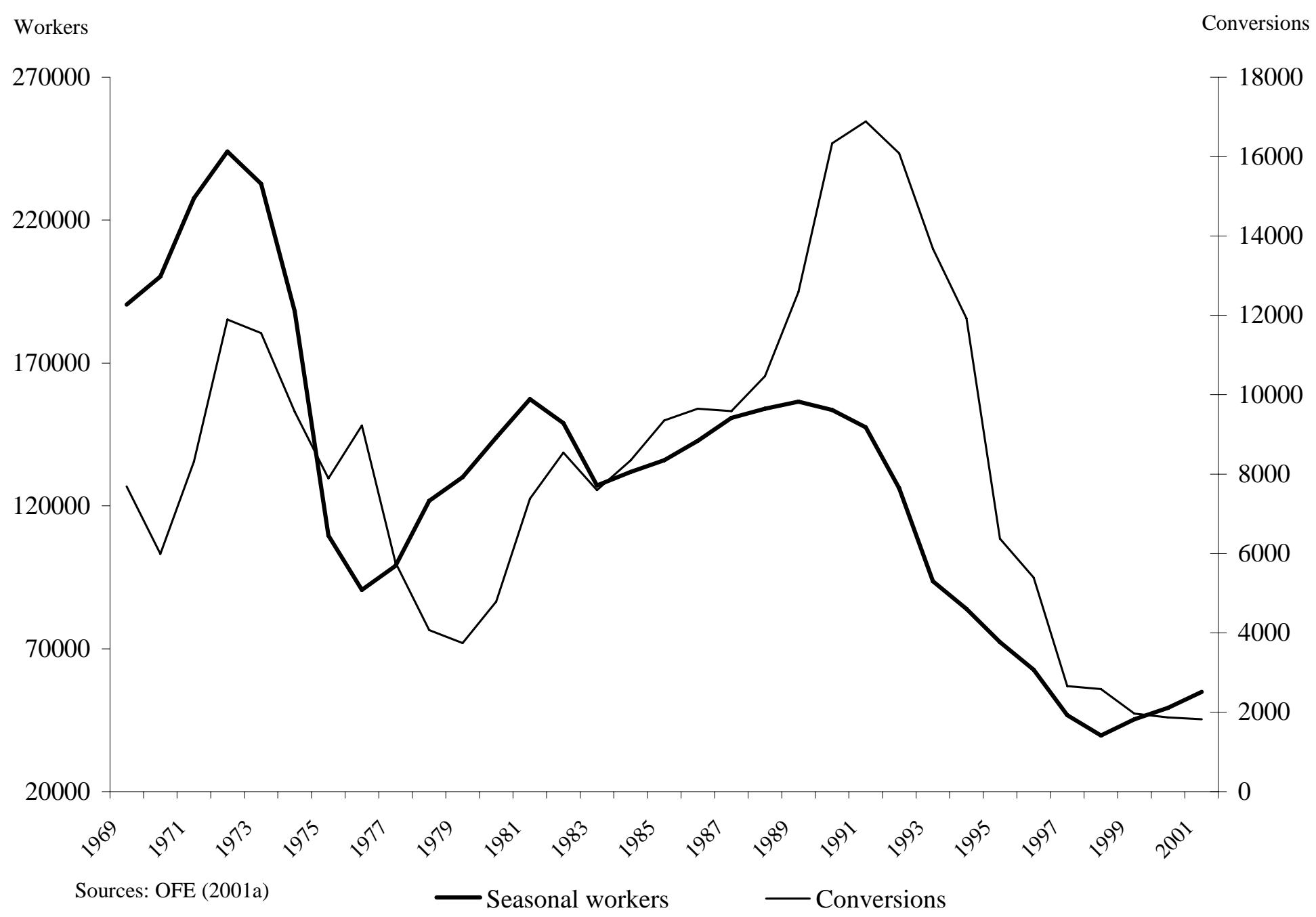


From 1990 to 1994, there are almost as many one-year permits allocated to workers who have a seasonal status as there are under the quota for newcomers. Two effects are at work: There is a large number of seasonal workers who have maintained an uninterrupted seasonal status throughout the 1980s and, newly signed agreements with Spain and Portugal shorten the residence period before conversion from 10 to 5 years. Finally, the children born from foreign parent receive the same status as their parent and therefore contribute to the rise in foreign permanent population. Since 1987, the number births in the foreign population has grown by more than 60\% to reach about 18,800 in 2003 .

In the 1980s and 1990s, the Swiss Government is quite successful in implementing its quota policy. However, it concerns only a small proportion of potential immigrants. In particular, graduation possibilities from less to more secure resident statuses encourage a large number of workers to reach for a more stable status and, for example, by 2003, 95\% of the Italian and Spanish residents in Switzerland have an establishment permit (IMES, 2004b, p.24). Also, a more generous family reunion regulation, as well as a larger than usual number of international crises, contribute to increasing the inflows further. In short, the quota-controlled component of the inflow is much too small to generate a strong effect on the level of permanent foreign population. Yet, this is not the only shortcoming of the system. In the next sub-section, we show that the outflow did not evolve as the Swiss authorities' expected, thereby contributing also to the continuous growth of foreign population. 


\subsection{The outflow}

In Figure 5, the two main components of the outflow from the permanent foreign resident population are exits from the country (approximately 73.7\%) and naturalizations (about 17.2\%).

The rotation principle relies on economic incentives to stimulate returns to home countries and act as automatic stabilizer for the foreign resident population. Implicit behind this assumption is a proportionate adjustment of exits to new entries in the medium term. While the experience from the early 1970s may have comforted the Government in its thinking (see Figure 3 in Section 2.2.) it is quite clear that, since then, the outflow has been following an independent path. It is constant in the 1980s and, steadily declining since the mid-1990s to reach its lowest level in 30 years despite the record high number of foreign residents. In 1996, the annual outflow rate is $5.5 \%$ and in 2003 , it is $3.1 \%$.

Unlike in the 1970s, in the early 1990s the economic slowdown does not engender large returns of foreign residents to their home countries even though it is as deep. While almost 400,000 foreign people leave Switzerland between 1974 and 1977, that is approximately $40 \%$ of the foreign population, only about 275,000 people leave between 1990 and 1993 that is $23.4 \%$ of the permanent resident population. As a result, the migration balance remains overwhelmingly positive throughout the period despite a sharp drop in inflow.

Interestingly, the evolution of the two categories of permanent residents, i.e., oneyear and establishment permit holders, is quite different. Similarly to the 1970s, the recession of the 1990s generates a sudden and brief peak in the outflow of foreigners with 
establishment permits. By contrast, the outflow of people with one-year permits follows steadily a positive trend started in the mid-1980s already. Two factors may be at the source of the weaker response of the outflow to the rise in unemployment. First, in the 1990s, there is general unemployment insurance and employees have compulsory pension plans (ILO, 2004, pp 373-78 and $\mathrm{CH}, 2003$, 2004c). Second, there is convergence in standards of living between Switzerland and some major immigrants' source countries. The rise in exits is mostly due a larger than usual outflow of Spanish and Portuguese citizens and to a lesser extent, Italian. ${ }^{16}$ The ratio of income per capita between 1974 and 1992 decreases from 3.14 to 2.4 with Italy, 3.72 to 3.09 with Spain and 5.82 to 4.22 with Portugal. Hence, "making money" in Switzerland to have a better life at home later has become a much less attractive proposition in the 1990s. One additional factor may have a specific impact on the outflow of Spanish and Portuguese workers. Most of the rise occurs during $1992^{17}$ and January 1,1992 is the date of effective free mobility for workers from the two countries within the European Union (see, Gross and Schmitt, 2005). This new opportunity may have contributed to some people’s decision to leave Switzerland and locate in the EU. Therefore, it seems that economic and institutional changes have rendered the rotation assumption obsolete by the 1990s and exits of permanent foreign residents can no longer be considered an automatic stabilizer of the level of foreign population.

The other channel likely to affect the recorded level of foreign permanent residents is naturalization. Even though it doubles between 1990 and 2000, Switzerland

\footnotetext{
${ }^{16}$ In 1990 and 1991, the three countries combined represented about 39\% of the outflow; in 1992, 46\% and in 1993, 40\% (IMES, 2004a).

${ }^{17}$ In 1992, the outflow of Spanish and Portuguese workers is about 59\% and 88\% higher than in 1990 (only $31 \%$ for Italian workers; OFE, 2001a, Table 12.21.R, p.54).
} 
remains one of the OECD countries with the lowest rate. In 2000, only $2.1 \%$ of foreign population become citizens while in other small European countries such as Austria, Norway, and Sweden, 3.3\%, 5.3\% and 8.9\% do (see Table 4). ${ }^{18}$

Table 4: Acquisition rate of nationality in some OECD countries

\begin{tabular}{|l|c|c|c|}
\hline & 1990 & 1995 & $\mathbf{2 0 0 0}$ \\
\hline Switzerland & 1.0 & 1.3 & 2.1 \\
\hline Austria & 2.4 & 2.1 & 3.3 \\
\hline Denmark & 2.0 & 2.7 & 7.3 \\
\hline France & $2.7^{\mathrm{a} /}$ & - & $4.5^{\mathrm{b} /}$ \\
\hline Germany & 2.7 & 4.5 & 2.5 \\
\hline Italy & $0.6^{\mathrm{a} /}$ & 0.8 & 0.8 \\
\hline Japan & 0.7 & 1.0 & 1.0 \\
\hline Netherlands & 4.9 & 9.4 & 7.7 \\
\hline Norway & 3.5 & 7.2 & 5.3 \\
\hline Spain & 1.5 & 1.5 & 1.5 \\
\hline Sweden & 5.9 & 6.0 & 8.9 \\
\hline UK & 2.4 & 2.0 & 3.7 \\
\hline
\end{tabular}

Sources: OECD $(2004,1999) .{ }^{a /} 1991{ }^{b /} 1999$.

There are several reasons why Switzerland exhibits such a low rate and the most obvious is legal constraints. Administrative requirements are extremely cumbersome, their evaluation is subjective, the monetary cost, in some instances quite high, and the result is not guaranteed.

In Switzerland, naturalization is coupled with acquiring citizenship from the municipality and canton (equivalent to state or province in other countries) of residence, and three political levels are involved in the process. The federal legislation fixes the basic minimum requirements for regular and accelerated naturalization. For regular

\footnotetext{
${ }^{18}$ Large European countries such as Germany, Spain and Italy, however have similar or lower rates (2.5\%, $1.5 \%$ and $0.8 \%$ respectively).
} 
naturalization, the criteria are a minimum of 12 years of residence in Switzerland, ${ }^{19}$ three of which in the last 5 years before application; proof of integration in the Swiss society (social integration); knowledge of the Swiss way of life and Swiss habits and customs (cultural integration); respect of the judicial order; no threat to interior and exterior security of Switzerland. Accelerated naturalization is available to people whose spouse or one parent has the Swiss nationality and the residence requirement is shorter (i.e., 6 years).

The cantons determine the decisions to be delegated to municipalities and have their own requirements for years of residence. The two extremes in the French-speaking part of Switzerland are 1 year during the last 5 years in Geneva and, 5 full years before the application in Valais. Among the tasks attributed to cantonal and municipal authorities are the evaluation of the degree of compliance with federal criteria (i.e., the evaluation of the degree of cultural and social integration) and the decision of naturalization. Interestingly, there is no unified system and each canton decides which level of jurisdiction is in charge; naturalization decisions can be taken by especially setup decision committees made of various types of elected officials, by the executive arm of the local Government or, by popular vote. ${ }^{20}$ Finally, the fee charged for the process is not uniform across cantons. In the French-speaking part of the country, it varies between SFr330 (about US\$287) and SFr20,000 (US\$17,400). In one canton, for people 25 years and older, it is a two-level charge with a basic fee set at SFr300 (US\$261) and a variable

\footnotetext{
19 This is the highest residence requirement in Europe. Italy, Spain and Austria require 10 years of residence and Germany and Greece follow with 8 years (Wanner et d'Amato, 2003, Tableau 1, p.14).

20 This latter system recently generated controversial decisions. For example, in March 2000, the municipality of Emmen rejected 19 out of the 23 applicants. Some had been living in Switzerland for more than 20 years and the results raised allegations of racism because all the rejected cases were citizens from
} 
component equal to $5 \%$ of annual gross income. Finally, the whole process takes on average 3 years (Le Temps, 2004).

Another reason for low naturalization rates is that citizens of EU countries which do not recognize dual citizenship are reluctant to acquire the Swiss nationality as they would lose access to the whole European market. Spain, for example, does not recognize dual nationality for its expatriates while Italy does (Wanner et d'Amato, 2003, p. 25) and the proportion of residents originating from these two countries who acceded to Swiss citizenship shows large differences. Between 1986 and 1990, on average 0.7\% of Italian and 0.5\% of Spanish long-term residents became Swiss citizens. Between 1996 and 2000, the rates were $2.3 \%$ and $0.6 \%$ respectively.

Despite the unfavorable administrative environment, the number of regular and accelerated naturalizations increases steadily throughout the 1990s. The reasons for this evolution are diverse. ${ }^{21}$ First, in January 1992, the Federal Government introduces an amendment to the legislation, which modifies it in two significant ways. It creates a faster procedure for the naturalization of the Swiss citizens' foreign spouses by eliminating an obvious discriminatory treatment between men and women $^{22}$ and, the requirement for new citizens to renounce their former citizenship is eliminated. Second, in 1994, following the rejection by popular vote of a new legislation that would have eased the naturalization process for young foreigners (see Annex I, Table A.I.2), several cantons

the same region of the world (Le Temps, 2000). The Federal Court, in July 2003, had to reconfirm that all negative decisions must be substantiated and appeal right must be granted to applicants.

21 For more details, see CH (2003a) and Wanner et d'Amato (2003).

${ }^{22}$ Under the old legislation, a man married to a Swiss woman had to go through the regular procedure while a women married to a man became automatically Swiss by marriage. The new amendment requires men and women to live for 3 uninterrupted years with their spouse in Switzerland before applying (OFE, 2001a, 
simplify significantly the procedures for $2^{\text {nd }}$ and $3^{\text {rd }}$ generation 16 to 24 years old youth. Third, the growth of the population of $2^{\text {nd }}$ and $3^{\text {rd }}$ generation foreigners increases the probability of mixed marriages, and thus, access to the accelerated procedure. The share of such marriages rises from 20\% in 1986 to 31\%, in 1997 (Piguet, 2004, p.101).

Acquiring the Swiss nationality is a long and tedious process with no guarantee of success. Several popular votes have rejected changes to the naturalization legislation that would simplify and accelerate naturalization for young $2^{\text {nd }}$ and $3^{\text {rd }}$ generation foreigners. The September 2004 vote is the third such rejection since 1983 (see Annex I, Table A.I.2). Moreover, recently, discrimination appears to have infiltrated the naturalization decision process in some regions, making the outcome even more uncertain for some foreigners. Yet, at the same time, several municipalities and cantons where the population voted with a majority in favor of these new legislations have eased and harmonized their own requirements, be they monetary or administrative. The fact remains that because the decision on naturalization is decentralized, large inequalities of treatment of applicants exist across the country and the political pressure is rising to eliminate the potential for discriminatory behavior.

\subsection{Quotas on flows of workers: An evaluation}

The Swiss immigration policy was designed in 1970 when there was an acute shortage of labor and mounting political pressure to control the level of foreign population and, for 30 years, its two premises, quotas on inflows of workers and the

p.80). The change in legislation also explains the drastic fall in certified and automatic naturalizations in Figure 5. 
rotation assumption, have hardly changed. The policy remains unchanged despite institutional and economic developments that affected the effectiveness of both instruments to regulate the level of foreign population. The possibility of converting seasonal status into permanent resident status with the accompanying right to family reunion increasingly weakens the link between quotas (even though strictly enforced) and the foreign population growth. Also, the introduction of unemployment insurance in the early 1980s as well as the more stable status foreign residents achieves as time passes, seriously diminish the power of the rotation principle as an automatic stabilizer. One may wonder why Swiss authorities did not consider applying quotas to all classes of new immigrants like the so-called immigration countries. Both Canada and the United States, for example, have had for decades annual ceilings on the total inflow of immigrants whatever the class they come under (see Green, 1995). Similarly why didn't the Government recognize earlier that the rotation assumption was no longer supported by the facts? It is difficult to imagine that the Swiss authorities did not understand these evolutions. The answer may partly lie in the Government's determination, since the mid1980s, to address the chronic shortage of labor in the Swiss economy while preserving the chances of a better economic integration with the EU. This position is clearly reflected by the 3-, later 2-circle model that gives priority to European citizens and limits immigration from the rest of the world to skilled labor. That model is a step in the direction of introducing free mobility of labor with EU/EFTA countries. 


\section{Who are the foreigners?}

Over time, the close management of new work permits (number and allocation) has had an impact on the characteristics of the immigrant population creating biases which have been criticized by pressure groups because of their economic consequences. In this section we take a closer look at the distribution of countries of origin, skill levels and sectoral employment of immigrants.

\subsection{Countries of origin}

Until 1990 and the implementation of the three-circle model, there is no discriminatory regulation for immigration from different regions of the world. Between 1970 and 1990, the majority of the inflow is from EU/EFTA countries, ${ }^{23}$ but their share declines steadily from $78.7 \%$ in 1970 , to only $54.7 \%$, in 1990 . That fall is reflected in the inflow of foreigners entering the labor force (83.6\% to $62.3 \%)$ as well as those not entering the labor force (68.2\% to $46.1 \%)$. By motives, the family reunion category experiences almost a 50\% drop in the EU/EFTA component (i.e., from 82.3\% in 1970 to $48.4 \%$ in 1990). The conversion of seasonal into longer-term permits also falls from 97.2\% to $64.6 \%$ for EU/EFTA countries. Yet not all EU/EFTA countries experience a similar evolution, and the composition for the rest of the world also changes (see Figure 8).

\footnotetext{
${ }^{23}$ The composition of EU/EFTA is maintained constant throughout the period under discussion that is EU15 and Iceland, Lichtenstein and Norway.
} 
Figure 8: Distribution of immigrants for some regions of origin

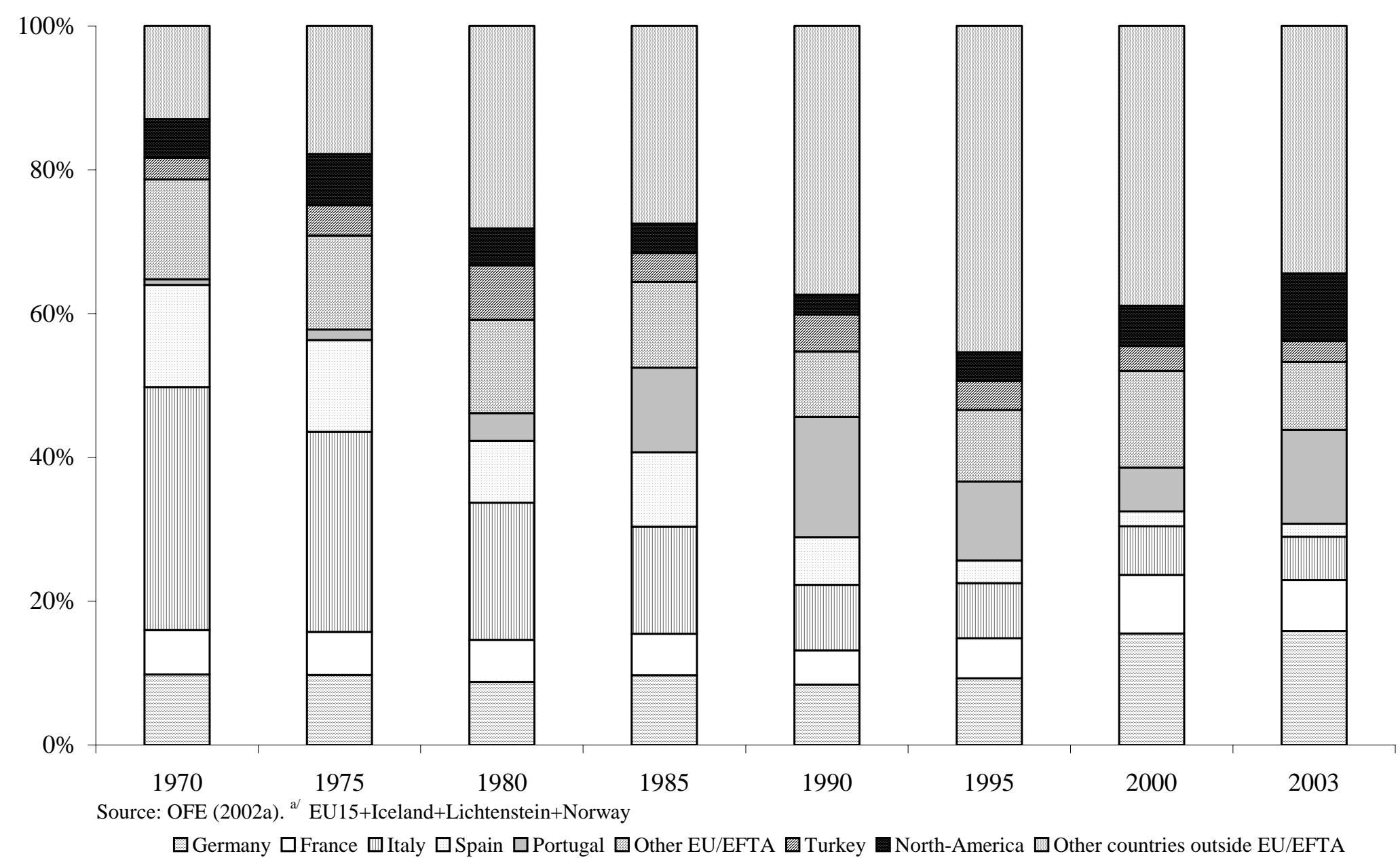


While the share of French and German immigrants hardly changes between 1970 and 1990, the number of immigrants from Italy and Spain declines steadily from more than 35,000 to about 10,700 for the former and from approximately 12,800 to about 4,500 , for the latter. In 1990, immigrants come increasingly from Portugal and from outside the EU/EFTA in particular Eastern Europe, Asia and South and Central America (together, in 1990, almost 1/3 of the new permanent residents). Also, immigration from North America has shrunk to 2.8\% from a peak of 7.1\% in 1975. This gradual shift in ethnic composition of the inflow is at the source of increasing political pressures which led to the three-circle model with differentiated treatment of immigrants according to their nationality. Initially, the new approach which gives priority to EU/EFTA workers is not very successful in altering the distribution. For example, in 1995, workers from the rest of the world represent an even greater share, $53.4 \%$ against $45.3 \%$ five years earlier. Citizens from the Former Yugoslavia, to whom new permits are awarded only under exceptional circumstances, represent $26 \%$ of the inflow of newcomers in 1995. In fact $67 \%$ of them come under the family reunion class and $9.1 \%$ are conversions of seasonal permits. ${ }^{24}$ In addition, about 1370 people (5.6\%) are asylum seekers who obtain the right to stay in Switzerland that year. Also, 41\% of immigration from Turkey is through the family reunion class.

By 2000, however, a change in source countries distribution is starting to develop and in 2003, immigrants from the EU/EFTA countries represent more than half of total inflow for the first time since 1990. North America's share has more than doubled in 8 years (from $4 \%$ in 1995, to $9.4 \%$ in 2003). Asia and Central and South America have increased further (to $12.4 \%$ and 5.8\% respectively) and Eastern Europe has dropped mostly because of the Former Yugoslavia,

\footnotetext{
${ }^{24}$ See ble 112.2R, p.42.
} 
which is now down to $10.3 \%$. These changes reflect the characteristics of the new policy: First, preference given to EU/EFTA countries for all types of jobs and, second, entries under quota for only skilled workers from the rest of the world.

\subsection{Distribution of skills}

In the early 1990s, employers complain that the immigration policy is inadequate on two fronts: The allocation of permits is too political and the policy is biased towards attracting unskilled labor while skilled immigrants are needed. The closely managed allocation of the quotas coupled with the fact that holders of one-year permits do not benefit from professional and geographical mobility (see Section 3.1.) may have maintained undue rigidity in the system. The Government's argument for doing so is the need to help restructure the Swiss economy (Piguet, 2004, Chapter 6, pp 47-56). Figure 9 helps evaluate whether there is a bias in the skill distribution of immigrants compared to Swiss workers. ${ }^{25}$

\footnotetext{
${ }^{25}$ Four categories of skills have been created from 11 occupation categories: High skill=top managers+scientists and intellectuals; Mid skill=middle managers+administrative employees; low skill=craftspeople+farmers+blue-collar workers; unskilled=drivers and assemblers+unskilled (OFS, 2004a, Table T.3.2.1.10).
} 


\section{Figure 9: Distribution of skills}

Distribution of skills in foreign employment: 1991

Distribution of skills in Swiss employment: 1991
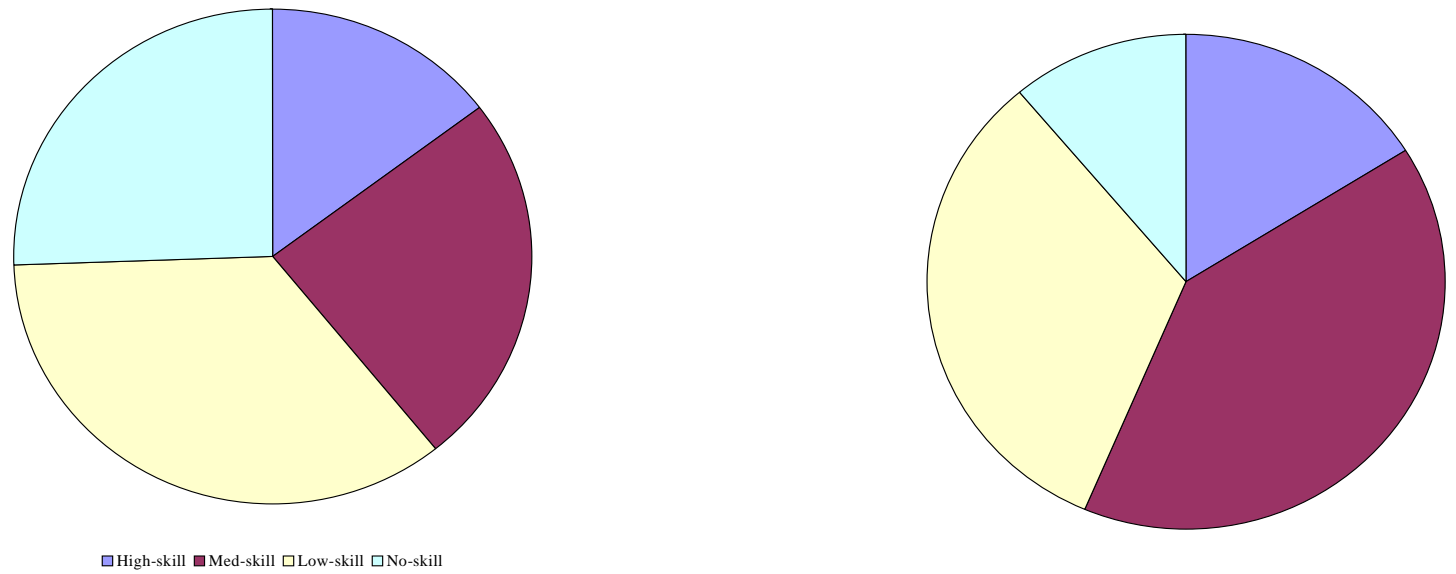

口High-skill $\square$ Med-skill $\square$ Low-skill $\square$ No-skill

Distribution of skills in foreign employment: 2003

Distribution of skills in Swiss employment: 2003

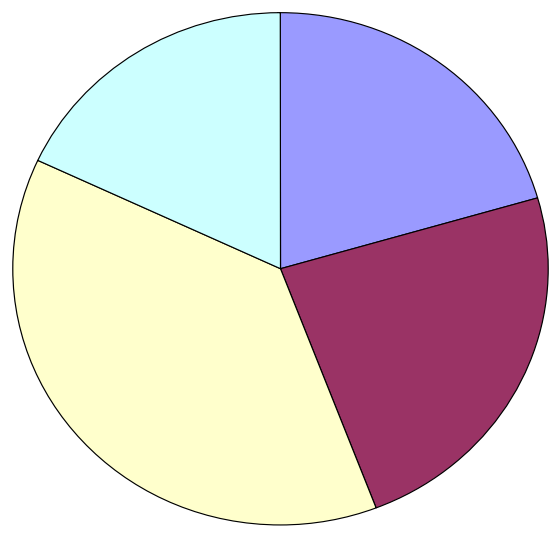

$\square$ High-skill $\square$ Med-skill $\square$ Low-skill $\square$ No-skill

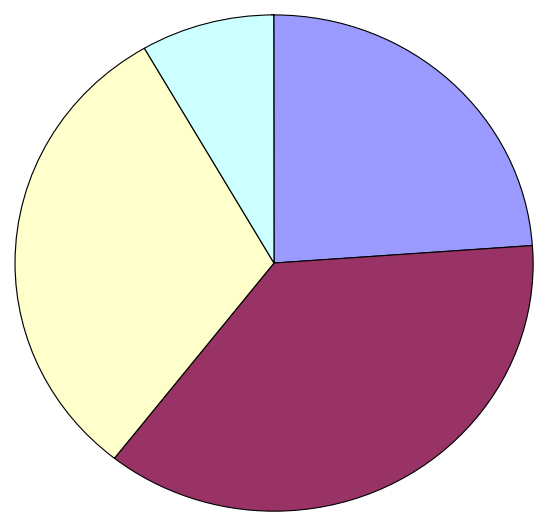

口High-skill $\square$ Med-skill $\square$ Low-skill $\square$ No-skill

In 1991, the shares of high and low skill workers in both groups are very similar (14.8\% for foreigners vs. $16.1 \%$ for the Swiss with high skills and $35.1 \%$ vs. $32.5 \%$ with low skills), but there are major differences in the middle and the extreme low end of the distribution. Swiss 
workers with mid-level skills represent $40.1 \%$ of employees while foreigners, only $24.5 \%$. At the very low end, Swiss make up $11.2 \%$ of employment and, foreigners, $25.6 \%$.

By 2003, some obvious changes have taken place. Swiss employment on average has moved toward a higher skill level and the share of highly skilled has increased by almost 8 percentage points to reach $23.9 \%$. All other shares have decreased with that of unskilled employment dropping by almost 3 percentage points. Foreign employment despite experiencing an even larger drop in the proportion of unskilled workers (7.5 percentage points) still registers a larger share than Swiss employment. Gains are made in the highly skilled category but to a lesser extent than for the Swiss (18.1\% vs. 8.4\%). Therefore, there is skill improvement in both groups but foreign employment still lags behind. In fact things are likely to keep improving as immigration in very recent years shows much higher skill content than in the past. In 2002-2003, more than $50 \%$ of 18 -year old adults who migrated to Switzerland as permanent resident have a university degree or equivalent training. By comparison only $35.9 \%$ (18.6\%) of foreign jobholders who have been living in Switzerland between 5 and 10 years (more than 10 years) do (OFS, 2004b). Hence, the skill distributions of the two groups are becoming increasingly similar even though unskilled industries which have long been considered unattractive by Swiss workers such as construction, hospitality, retail trade and machinery still concentrate a large share of the foreign labor force (about 44\% in 2001, OFE, 2001b, Table 324.1R, p.102).

\subsection{Distribution across sectors}

A convergence is also observed when looking at broad economic sectors (Table 5). 
Table 5: Level of sectoral employment

\begin{tabular}{|l|c|c|c|c|c|}
\hline & $\mathbf{1 9 7 8}$ & $\mathbf{1 9 8 5}$ & $\mathbf{1 9 9 0}$ & $\mathbf{1 9 9 5}$ & $\mathbf{2 0 0 1}$ \\
\hline & \multicolumn{5}{|c|}{ Working labor force (,000) } \\
\hline Primary & 223 & 203 & 162 & 175 & 175 \\
& $(7.3 \%)$ & $(6.1 \%)$ & $(4.2 \%)$ & $(4.4 \%)$ & $(4.2 \%)$ \\
\hline Secondary & 1,181 & 1,193 & 1,229 & 1,133 & 1,062 \\
& $(38.6 \%)$ & $(35.6 \%)$ & $(32.2 \%)$ & $(28.6 \%)$ & $(25.6 \%)$ \\
\hline Tertiary & 1,659 & 1,958 & 2,429 & 2,649 & 2,918 \\
& $(54.2 \%)$ & $(58.4 \%)$ & $(63.6 \%)$ & $(66.9 \%)$ & $(70.2 \%)$ \\
\hline & \multicolumn{7}{|c|}{ Foreign labor force with permanent resident status (person) } \\
\hline Primary & 5,255 & 6,747 & 8,657 & 14,833 & 12,273 \\
& $(1.1 \%)$ & $(1.2 \%)$ & $(1.3 \%)$ & $(2.1 \%)$ & $(1.7 \%)$ \\
\hline Secondary & 290,196 & 302,491 & 348,851 & 325,714 & 286,130 \\
& $(60.2 \%)$ & $(55.8 \%)$ & $(52.5 \%)$ & $(45.3 \%)$ & $(38.7 \%)$ \\
\hline Tertiary & 186,612 & 233,248 & 307,381 & 384,216 & 440,429 \\
& $(38.7 \%$ & $(43.0 \%)$ & $(46.2 \%)$ & $(52.6 \%)$ & $(59.6 \%)$ \\
\hline
\end{tabular}

Source: OFS (2004a).

In 1990, 52.5\% of the foreign labor force is in the secondary sector while at the country level, the share of labor force working in the sector is 32.2\%. By 2001, the respective shares are $38.7 \%$ and $25.7 \%$ and more than $1 / 2$ of the foreign labor force is in the tertiary sector. This is a dramatic reversal from 1970 when the secondary sector represented $60 \%$ of the foreign labor force. Also, the substitution toward the tertiary sector occurred at a much faster pace in the 1990s than earlier (13.8 percentage points in the 1990s vs. 7.7 percentage points, in the 1980 s, see Table 5). Moreover, the distribution of the foreign labor force is heavily influenced by immigrants with establishment permits who entered the country at least a decade ago. In fact, the distribution of one-year permit holders in the labor force, who presumably have been in Switzerland for less than 10 years, is much closer to that of total labor force. In 2001, only $28.4 \%$ of these immigrants are in the secondary sector against $42.3 \%$ of those with an establishment permit. Also, the composition of the inflow across sectors clearly shows that the movement of substitution toward 
the tertiary sector continues. In 2003, only $23 \%$ of newcomers worked in the secondary sector against $73.5 \%$ in the tertiary sector.

To summarize, in the second part of the 1990s, there is a rather marked shift in the distribution of foreign workers' skill levels, and sectoral activity and it happens simultaneously to a relative increase in immigration from EU/EFTA and North America. These changes coincide with the focus of the 2-circle policy on giving priority to workers from EU/EFTA and on conditioning the allocation of quotas for other countries on skilled labor (see Section 2.3). It also reflects the diminishing interference of Government in the actual allocation of permits across enterprises. Hence, the more flexible $21^{\text {st }}$ century immigration policy appears to be finally succeeding in satisfying employers' demands and, as a consequence, foreigners better represent the overall labor force structure.

\section{The year 2002 and beyond}

In May 2000, the agreement on free mobility of people with EU15 and the 3 EFTA countries is approved by popular vote fulfilling the Government's hope that the dilemma of satisfying the needs of the economy and limiting the opposition to foreign residents can finally be put to rest. June $1^{\text {st }} 2002$ is the beginning of a transition period toward complete free mobility with restrictions to be progressively lifted until 2007..$^{26}$ For example, until May 31, 2004, employers must give priority to nationals and there is a monitoring of salary and working conditions. The former one-year permit is now extended to five year and there are short-term renewable permits for people from EU/EFTA countries with work contracts shorter than 12

26 This section draws on Piguet (2004), Chapter 13, OFE (2002a and 2002b). 
months. There are annual quotas for both types of permits until 2007. The quota on five-year permits set at 15,300 has been already overrun with 21,783 permits allocated in 2003 . However, the quota on short-term permits set at 115,700 is far from being exhausted. Between 2007 and 2014, a special protection clause allows Switzerland to impose quotas again in case of exceptional increase in migrations. The implementation of a similar agreement with the 10 new members of the EU except Malta and Cyprus will be put to the popular vote in September 2005. Finally, in the transitory period there are also some restrictions on border permits such as priority to Swiss workers and the job must be in the adjacent Swiss region. The initial duration of a border permit is extended from 1 year to 5 years, renewable and the person must go back weekly (rather than daily) to the foreign domicile. In 2007, geographical mobility will be guaranteed throughout Switzerland.

Most economic needs are expected to be accommodated by EU/EFTA workers and comprehensive immigration legislation is being drafted for citizens from other countries based on skill evaluation (point system). Meanwhile, the conditions set out in the two-circle model remain in place. One-year permits (up to a maximum of 4,000 per year), can be obtained only exceptionally and after potential employers have shown that there is a need for specific skills that are unavailable in the country (nationals, or foreign residents) or from EU/EFTA countries. Under the new legislation, however, a person with a one-year permit is likely to enjoy professional and geographical mobility to avoid lengthy spells of unemployment and, after 10 years, the permit could be converted into an establishment permit like in the previous system. Short-term permits for less than a year will also be under quota (maximum 5,000 per year). One major change from the 1970-policy is the elimination of the "graduation" principle between 
short-term and one-year permits as it was the case with seasonal permits. Family reunion is authorized without delay except for short-term permits.

Simultaneously, the asylum policy is being revised and integration policies are finally developed for all foreigners, refugees, workers and their families alike. After struggling for 40 years, the Swiss Government seems to be moving toward a comprehensive approach of the question of foreign population. The project for the new immigration legislation is in its last phase of development and voting by parliament is expected to start in Spring 2005 to be followed by a popular vote sometimes in the following years (Parlement Suisse, 2004).

\section{Conclusion}

In this paper we have surveyed the main features of Swiss immigration policy since the 1970s and derived some conclusions about their effectiveness. The goal of the immigration policy has been all along to stabilize the level of foreign resident population while not cutting off employers from the foreign source of workers. Until 2002, the government relied on two instruments, quotas on the inflow of new worker permits and the rotation principle, which assumes that individuals see migration as temporary. Yet, despite a successful control of the quotas the policy has been unable to affect significantly the evolution of the foreign resident population. In fact, the link between the instruments and the overarching political goal of slowing down the growth of the permanent foreign population has grown increasingly weak as time passed. In particular, the automatic graduation from seasonal to permanent status has raised steadily the number of the immigrants not affected by the quotas. The more secure status obtained by immigrants through the graduation system and institutional changes such as general unemployment insurance also invalidated the assumption that immigration is temporary. Yet this 
very meticulously designed and run immigration policy may have had some desirable effects. In many cases, seasonal workers returning annually to their home country were assured of a work contract for the following season and they could also look forward to the conversion of their status into right to residency after a number of years. In such system the incentive to stay illegally in the country at the expiry of the seasonal permit is likely to have been minimal. Eventually, workers and their family would acquire the right to permanent establishment. Hence, even though the desired goal has not been completely achieved, the policy may have been effective in stabilizing expectations of migrants.

In June 2002, the policy switched from very tight management of quotas to the first stages in the implementation of the free mobility with the EU/EFTA and a year later there are already signs that it is having an impact on the occupational and skill structure of immigrants which should alleviate the complaints employers had about the quota system. The next step is for the Swiss government to develop immigration legislation for newcomers from the rest of the world that will, hopefully, put to rest the pressures from nationalists while keeping employers satisfied. 


\section{References}

Arlettaz Gérald, and Sylvia Arlettaz, 2004. La Suisse et les Etrangers. Immigration et Formation nationale (1848-1933). Lausanne : Editions Antipodes.

Blanc-Chaléard, Marie-Claude, 2001. Histoire de l’Immigration. Editions La Découverte. Paris.

CH, Confoederatio Helvetica, 2004a. Loi fédérale sur le Séjour et l'Etablissement des Etrangers. LSEE. Nr 142.20. March 26, 1931. As of April 6. Bern.

, 2004b. Ordonnance concernant la Déclaration du Départ des Etrangers. Nr 142.212. January 20, 1971. As of October 26. Bern.

, 2004c. Loi fédérale sur la Prévoyance professionnelle Vieillesse, Survivants et Invalidité, LPP. Nr 831.40. June 25 1982. As of November 23. Bern.

, 2003a. Loi fédérale sur l'Acquisition et la Perte de la Nationalité, LN. Nr 141.0. September 29, 1952. As of June 24. Bern.

, 2003b. Loi fédérale sur l'Assurance-Chômage obligatoire et l'Indemnité en Cas d'Insolvabilité, LACI. Nr 837.0. June 25, 1982. As of June 24. Bern.

Green, Alan G., 1995, “A Comparison of Canadian and US Immigration Policy in the Twentieth Century." In Diminishing Returns. The Economics of Canada's Recent Immigration Policy. Edited by Don. J. DeVoretz. Toronto: C.D. Howe Institute and Vancouver: The Laurier Institution.

Gross, Dominique M., and, Nicolas Schmitt, 2005. "Migration Flows, Skills and Network." Mimeo. Simon Fraser University and University of Geneva. July.

, 1987, "Structural and Cyclical Unemployment. An Empirical Estimation." Unpublished Ph.D. Dissertation. University of Toronto. Toronto.

ILO, International Labour Office, 2004. ILO Migration Survey 2003: Country summaries. Social Protection Sector, International Migration Programme. Geneva.

IMES, Office Fédéral de l'Immigration, de l'Intégration et de l'Emigration, 2004a. Statistique des Etrangers 2003. Volume 2 : Résultats rétrospectifs. Berne.

, 2004b. Statistique des Etrangers 2003. Volume 1 : Effectifs et Mouvements. Berne.

Le Temps, 2004. “Les Procédures de Naturalisation en Suisse romande.” 28 Septembre. Genève. , 2000. “Laver la Honte d’Emmen.” 14 mars. Genève. 
Mahnig, Hans, and, Andreas Wimmer. 1998. "Zurich: Political Participation and Exclusion of Immigrants in a Direct Democracy.” Paper presented to the Third International Metropolis Conference. Israel. November 29-December 3.

OECD, Organization for Economic Cooperation and Development, 2004, 1999. Trends in International Migration: SOPEMI 2003 Edition. Paris.

OFE, Office Fédéral des Etrangers, 2002a. "Comparaison des Principaux Eléments : Réglementation en vigueur (LSEE /OLE), Projet de loi sur les étrangers (LEtr), Accord sur la libre circulation EU/AELE (avec délais transitoires).” Document d'information. 8 mars. Berne.

, 2002b. “Réglementation relative au Séjour et Procédures. Aperçu.” Département Fédéral de Justice et Police. Septembre. Berne.

, 2001a. Les Etrangers en Suisse. Mouvement de la population : Résultats rétrospectifs. Bulletin d'information statistique 2B. Berne.

2001b. Les Etrangers en Suisse. Effectifs: Résultats rétrospectifs. Bulletin d'information statistique 2A. Berne.

OFS, Office Fédéral de Statistique, 2004a. Encyclopédie statistique de la Suisse. Neuchâtel.

, 2004b, Communiqué de Presse : Vie active et Rémunération du Travail. No 03510401-00. 16 février. Service d’Information. Neuchâtel.

, 2002, Communiqué de Presse : Population. Immigration et Naturalisation. No 03510209-60. 13 Septembre. Service d’Information. Neuchâtel.

Parlement suisse, 2004. Loi sur les Etrangers. LEtr. http://www.parlament.ch/f/doauslaendergesetz-in-kuerze

Piguet, Etienne, 2004. L'Immigration en Suisse, 50 Ans d'Entrouverture. Collection Le Savoir Suisse. Lausanne : Presses polytechniques et universitaires romandes.

, and, Hans Mahnig, 2000, “Quotas d’Immigration: l’Expérience suisse.” Cahiers de Migrations internationales No 37. Service des Migrations internationales. Bureau international du Travail. Genève.

Straubhaar, Thomas, and, Peter A. Fischer, 1994, "Economic and Social Aspects of Immigration into Switzerland.” in European Migration in the Late Twentieth Century. Edited by Heinz Fassman and Rainer Münz. Aldershot, England: Edward Elgar Publishing Ltd.

US Census Bureau, 2004. The Foreign Born Population in the United States: 2003. Population Statistics. US Department of Commerce. Economics and Statistics Administration. August. Washington, DC. 
Viet, Vincent. 1998. La France Immigrée. Construction d'une Politique 1914-1997. Paris: Fayard.

Wanner, Philippe, and, Gianni d'Amato, 2003. "Naturalisation en Suisse. Le Rôle des Changements législatifs sur la Demande de Naturalisation.” Rapport préparé pour Avenir Suisse. Zurich. Juin.

WB, World Bank, 2004. World Development Indicators. Electronic Databank. Washington DC. 


\section{Annex I: Popular votes on immigration}

Direct democracy in Switzerland allows for the population to vote on most issues concerning immigration policy. New legislations as well as international agreements must be submitted to the popular vote. In addition, the population can develop "initiatives" to be submitted to popular vote for suggested changes in legislation or in the constitution provided enough signatures from citizens can be collected. Over the past four decades, a number of such initiatives in relation to the control of foreign population have been developed and submitted to popular vote.

Table I.1.: Popular initiatives on issues related to immigration

\begin{tabular}{|l|l|l|l|}
\hline & Name & Date of popular vote & $\begin{array}{l}\text { Result (\% popular } \\
\text { votes) }\end{array}$ \\
\hline & \multicolumn{2}{|l|}{ Initiatives to limit foreign population } & $\begin{array}{l}\text { Retired } \\
\text { March 20, 1968 }\end{array}$ \\
\hline 1. & $\begin{array}{l}\text { Initiative against the establishment of } \\
\text { foreigners. }\end{array}$ & - & Rejected (54\%) \\
\hline 2. & Initiative against foreign ascendancy. & June 7, 1970 & Rejected (65.8\%) \\
\hline 3. & $\begin{array}{l}\text { Initiative against foreign overpopulation of } \\
\text { Switzerland. }\end{array}$ & October 20, 1974 & Rejected (70.5\%) \\
\hline 4. & Initiative for the protection of Switzerland. & March 13, 1977 & Rejected (66.2\%) \\
\hline 5. & $\begin{array}{l}\text { Initiative to limit the annual number of } \\
\text { naturalizations. }\end{array}$ & March 13, 1977 & Rejected (67.3\%) \\
\hline 6. & Initiative to limit immigration. & December 4, 1988 \\
\hline 7. & Initiative to regulate immigration. & September 24, 2000 & Rejected (83.8\%) \\
\hline & Initiative in favor of foreigners \\
\hline 1. & $\begin{array}{l}\text { Initiative “standing by" in favor of a new } \\
\text { policy toward foreigners. }\end{array}$ & April 5, 1981 \\
\hline
\end{tabular}

Source: Adapted from Piguet (2004), Annex pp 141-143.

During the past 20 years, the Swiss Government has submitted new legislations on immigration and naturalization to the popular vote either in response to these initiatives or to maintain an open policy with the European Union. 
Table I.2.: Popular votes on legislations or agreements related to immigration

\begin{tabular}{|c|c|c|c|}
\hline & Name & Date of popular vote & Result \\
\hline & \multicolumn{3}{|c|}{ New legislation on immigration and international agreements } \\
\hline 1. & Revision of the LSEE ${ }^{\mathrm{a} /}$ from 1931. & June 6, 1982 & Rejected (50.4\%) \\
\hline 2. & Amendments to the $\mathrm{LSEE}^{\mathrm{a} /}$. & June 20, 1986 & Accepted (65.7\%) \\
\hline 3. & $\begin{array}{l}\text { Federal order on membership in the } \\
\text { European Economic Area. }\end{array}$ & December 6, 1992 & Rejected (50.3\%) \\
\hline \multirow[t]{2}{*}{4.} & Bilateral agreement with European Union & May 21, 2000 & Accepted (67.2\%) \\
\hline & \multicolumn{3}{|l|}{ Legislation on naturalization } \\
\hline 1. & $\begin{array}{l}\text { Project in favor of an easier naturalization } \\
\text { process for young foreigners. }\end{array}$ & December 4, 1983 & Rejected (55.2\%) \\
\hline 2. & $\begin{array}{l}\begin{array}{l}\text { Federal order for a revision of the } \\
\text { constitutional } \\
\text { naturalizations. }\end{array} \\
\text { legislation }\end{array}$ & December 4, 1983 & Accepted (60.8\%) \\
\hline 3. & $\begin{array}{l}\text { Federal order for a revision of the } \\
\text { constitutional legislation on the } \\
\text { naturalizations of young foreigners. }\end{array}$ & June 12, 1994 & $\begin{array}{l}\text { Rejected by a majority } \\
\text { of cantons }\end{array}$ \\
\hline 4. & $\begin{array}{l}\text { Federal order on easier naturalization } \\
\text { process for } 2^{\text {nd }} \text { generation young foreigners }\end{array}$ & September 26, 2004 & Rejected (56.8\%) \\
\hline 5. & $\begin{array}{l}\text { Federal order on the acquisition of } \\
\text { nationality for } 3^{\text {rd }} \text { generation foreigners }\end{array}$ & September 26, 2004 & Rejected (51.6\%) \\
\hline
\end{tabular}




\section{Annex II: Historical benchmarks in immigration policy}

1963: First ceiling to control foreign population. Permits are awarded only for workers in firms with less than 2\% increase in overall employment compared to December 1962.

1965: The double ceiling policy. (i) In each firm, the level of foreign workforce must be reduced to 95\% of its level at March 1, 1965. (ii) The total number of foreign workers employed cannot increase. Workers can no longer enter Switzerland only with a work contract. They must obtain a residence permit prior entry.

March 17, implementation of agreement signed with Italy. Guest workers can get oneyear permit after 5 years of uninterrupted seasonal permits. Family reunion can happen after 18 months rather than 36 months.

1970: The global ceiling policy with quota determined by the Government every November 1. The Government allocates a quota of permits to specific enterprises, which suffer from a shortage and then another allocation is made to the cantons proportionately to the population.

1976: Italian guest workers can get one-year permit after 4 years of uninterrupted seasonal permits.

1990: The 3-circle model. Countries are classified into three groups: EU/EFTA countries; countries outside these associations but with similarities with Switzerland (in human rights record, in style of living and with commercial links) for which there are quotas on the number of permits attributed; rest of the world, from which immigration is allowed only exceptionally and for qualified workers.

1991: Yugoslavia is put in the third circle because of its human rights record and there is no economic migration anymore allowed. It is also excluded from the seasonal work.

1992: December 6, popular vote rejects membership in European Economic Area.

1998: The 2-circle model. Preferential treatment for EU/EFTA. Employers' economic needs satisfied by EU/EFTA workers. Highly qualified people can come from all other countries.

2000: May. Approval of the bilateral agreement with EU on free mobility by popular vote.

2002: June 1. Implementation of the first phase of bilateral agreement with EU.

2004: June 1. Implementation of the second phase of bilateral agreement with EU.

2005: March. Expected vote by the Senate on the new immigration legislation project.

(Arlettaz and Arlettaz, 2004, Piguet, 2004, and Piguet and Mahnig, 2000). 